\title{
Cross-Sectional Damage Index for RC Beam-Column Members Subjected to Multi-Axial Flexure
}

\author{
Satoshi Tsuchiya ${ }^{1}$ and Koichi Maekawa ${ }^{2}$
}

Received 8 October 2005, accepted 27 November 2005

\begin{abstract}
A damage index for seismic performance of RC members is proposed on the basis of 3D multi-axial fiber analysis. The elasto-plastic and fracturing model for concrete compression is applied for estimation of the fracture parameter, which is defined as the reduced elastic stiffness for each micro-cell component of member cross sections. The averaged fracture parameter over the cross section is treated as the index of cross-sectional damage for the remaining axial force-carrying mechanism. This index provides an approximation of damage related to seismic performance level II (reparable after seismic actions) not only for one-directional but also multi-axial flexure. This method is also effective for RC members confined by lateral ties.
\end{abstract}

\section{Introduction}

As numerical analysis capabilities become increasingly powerful, code-writing bodies have been discussing the establishment of nonlinear dynamic analysis for seismic performance assessment in practice. In JSCE standard specification 2002 (JSCE 2002), nonlinear response analysis in the time domain is specified as a key tool for examining earthquake resistant capability, and mechanical models for materials are provided. As increases in processing capabilities have in effect eliminated the processing burden associated with $3 \mathrm{D}$ analysis, new schemes for the effective application of powerful numerical methods are called for. Dynamic analysis with nonlinear material models offers not only integrated response variables such as displacement and cross-sectional forces, but also local intrinsic values such as strain, stress and plastic-damaging histories. The latter information is straightforward for magnitude of material damage and closer to some solid physical states than conventional indexes based on curvature or displacement. In order to make the most of the merits of nonlinear dynamic analyses, a practical performance index and its limit values are required for simple and effective use of huge amounts of 3D analysis results in the limit state design scheme.

The design code for underground LNG storage tanks (JSCE 2002, JSCE1999) was the first to provide performance assessment methods based upon 3D nonlinear dynamic analysis and clearly specify the design limit state in terms of principal compressive strain of RC shells. If the structural response exceeds this limit, seri-

\footnotetext{
${ }^{1}$ Representative Director, COMS Engineering Corporation, Japan. E-mail:satoshi@comse.co.jp

${ }^{2}$ Professor, Department of Civil Engineering, University of Tokyo, Japan.
}

ous irrecoverable damage is considered to remain (Kaizu et al. 2002) and the structure will rarely be repaired for re-use after an earthquake. Here, let us direct our attention to a feasible index for RC beam-column members. The maximum experienced strain can function as the damage index of $\mathrm{RC}$ shells but the following problems may arise for RC beam-column cases:

1) The strain gradient is considerably sharper compared to that of shell structures and the maximum strain may indirectly represent the mechanistic state of only a localized region with negligibly small volume in practice. This cannot represent damage incurred at the member level. In the case of shells, the strain field is almost uniform under shear and similar magnitude of material damage is distributed over a wide area. The maximum strain among all component elements is approximately associated with structural damage.

2) Computed local point-wise strains tend to be greatly affected by finite element discretization in detail unlike nodal displacements that result from the integral of all local strains. In the case of shells, the mesh definition is insensitive to the local strain computation because of a rather uniform strain field over the analysis domain.

Thus, an appropriate damage index is desirable in consideration of the characteristic states of stress and strains for RC beam-columns under sustained axial forces. In this study, the authors propose a new cross-sectional damage index to represent mechanistic capacity based on the integral of the local fracture parameter (JSCE 2002, Tsuchiya et al. 2003), which is equivalent to the elastic energy absorption capacity of concrete solids. This study also aims to identify a limit state criterion corresponding to seismic performance level II where the structure may maintain a stable axial load-carrying mechanism even after large seismic actions. While shear failure damage is out of the scope of this paper, sufficient shear reinforcement is assumed to be provided. 


\section{Fracture parameter of concrete and cross-sectional damage index}

\subsection{Analytical model}

In this study, the so-called fiber model is chosen as a design oriented tool for RC frames. The stress field is assumed to be one-dimensional along the member axis and the Euler-Kirchoff's in-plane hypothesis is applied; that is, axial fiber strain linearly develops according to the distance from the neutral axis. The member cross section is divided into small micro-cells on which constitutive models of concrete and reinforcing bars are defined (Tsuchiya et al. 2001). In this study, an elasto-plastic and fracturing model that consists of compression, tension, re-contact of the crack plane and hysteresis damping paths as shown in Fig. 1 (Maekawa et al. 2003) is applied for concrete. The strain rate effect and element size consistency are taken into account for strain softening after the compressive strength (El-Kashif et al. 2004a, b, Maekawa et al. 2004). A simplified model equivalent to Kato's model (Kato 1979 ) is used for the cyclic behavior of reinforcement. For computing the average stress from the average strain of the main reinforcing bars after buckling, the model by Dhakal et al. (Dhakal et al. 2002a, b) rooted in Pinto et al. (CEB 1996) is employed. As explained in Chapter 5, the confinement effect by lateral ties over the cross section is also considered through the fiber modeling of confined concrete and its effect is incorporated into the damage index discussed in this paper.

Details of these analytical and material models, as well as their applicability, are discussed in the references (Maekawa et al. 2003, Okamura et al. 1991). The shear deformation resulting from varying amounts of lateral ties are not considered, but the effect of lateral tie arrangement is considered in connection with the buckling length of the main reinforcing bars. When post-peak behavior is targeted, compression softening under lateral confinement has to be further considered with spalling off of cover concrete. If these characteristics are ignored, a more careful safety assessment is needed in general, while ignoring the confinement effect leads to a conservative safety assessment.

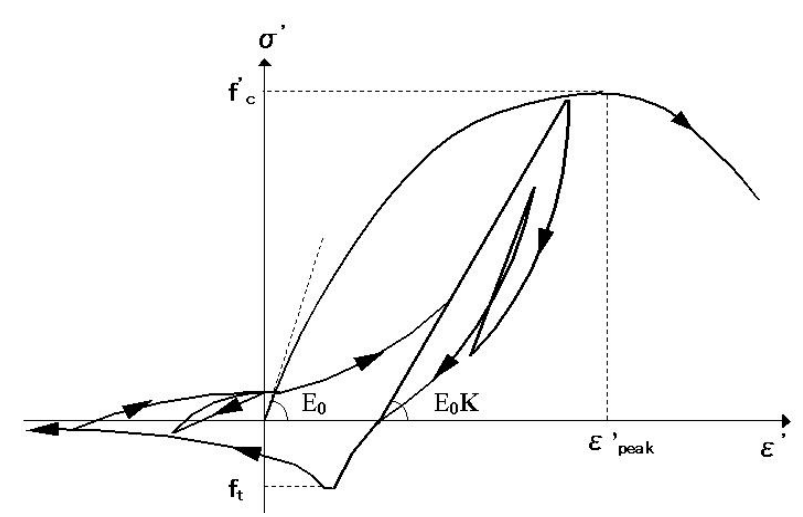

Fig. 1 Material models and fracture parameter of concrete.

\subsection{Cross sectional damage index}

Constitutive model based analysis may produce intrinsic solid-mechanical variables as well as displacement and sectional forces. Among them, the authors focus on the fracture parameter of concrete, which is calculated for each micro-cell during the whole time step. Here, the fracture parameter can be strictly defined as the reduced elastic stiffness on unloading-reloading paths normalized by the initial elastic stiffness. In a full-3D stress states, this value represents the capability to store shear elastic strain energy per unit volume (Maekawa et al. 1993). This parameter is defined as unity in the initial non-damaged state, and can potentially reach zero at complete shear collapse of the material. As the compression failure mode of core concrete is highly shear behavior accompanying lateral volumetric expansion, it logically is closely linked with the axial force-carrying mechanism. The 3D elasto-plastic and fracturing model for normal-strength concrete can be reduced to uni-axial states described by Eq. (1) to Eq. (3) (Maekawa et al. 2003) as,

$$
\begin{aligned}
& \sigma^{\prime}=E_{0} K\left\{\varepsilon^{\prime}-\varepsilon_{p}^{\prime}\right\} \\
& K=\exp \left[-0.73 \varepsilon_{\text {max }}^{\prime}\left\{1-\exp \left(-1.25 \varepsilon_{\text {max }}^{\prime}\right)\right\}\right] \\
& \varepsilon_{p}^{\prime}=\varepsilon_{\text {max }}^{\prime}-20\left\{1-\exp \left(-0.35 \varepsilon_{\text {max }}^{\prime}\right)\right\} / 7
\end{aligned}
$$

where $K=$ fracture parameter, $\varepsilon^{\prime}=$ axial total strain normalized by $\varepsilon_{\text {peak }}$ ' (i.e. the strain corresponding to compressive strength), $\varepsilon_{\mathrm{p}}{ }^{\prime}=$ normalized plastic strain, $\varepsilon_{\max }{ }^{\prime}=$ maximum experienced value of normalized strain, $\sigma^{\prime}=$ compressive stress normalized by uni-axial compressive strength, and $E_{o}=$ constant $(=2.0)$.

Taking into consideration 1) and 2) in Chapter 1, the authors hereafter discuss the sectional averaged value of the local fracture parameter $K(\mathrm{x}, \mathrm{y})$ within an entire referential section. Since it is useful to set the parameter to zero at the initial non-damaged state and to unity upon complete failure in a performance evaluation scheme, $\{1-K(\mathrm{x}, \mathrm{y})\}$ is chosen as the damage indicator. Its space-averaged value within a referential section is determined as the cross-sectional damage index $\bar{F}$ as given by,

$$
\bar{F}=1-\bar{K} \equiv \frac{1}{A_{c}} \int_{A_{c}}(1-K) d A \approx 1-\frac{\sum K \cdot \Delta A}{A_{c}}
$$

where $\bar{F}=$ cross-sectional damage index, $\bar{K}=$ average fracture parameter varying in time and location along the member axis, $K=$ local fracture parameter for each microscopic cell, and $A_{c}=$ cross-sectional area of concrete. The maximum value of $\bar{K}$ in time and space is the limit state index to represent sectional damage, as illustrated in Fig. 2.

When compression softening takes place, the strain field is no longer uniform but largely localized. Thus, 
the average strain defined on the control volume (or finite element size) may apparently depend on its size. Equations (1) to (3) are applicable to the control volume of $200 \mathrm{~mm}$ (Lertsrisakulrat et al. 2001, Nakamura et al. 2001 ) in length. If a different element length is specified, the space averaged stress-strain relation shall be adjusted so that the compressive fracture energy equi-

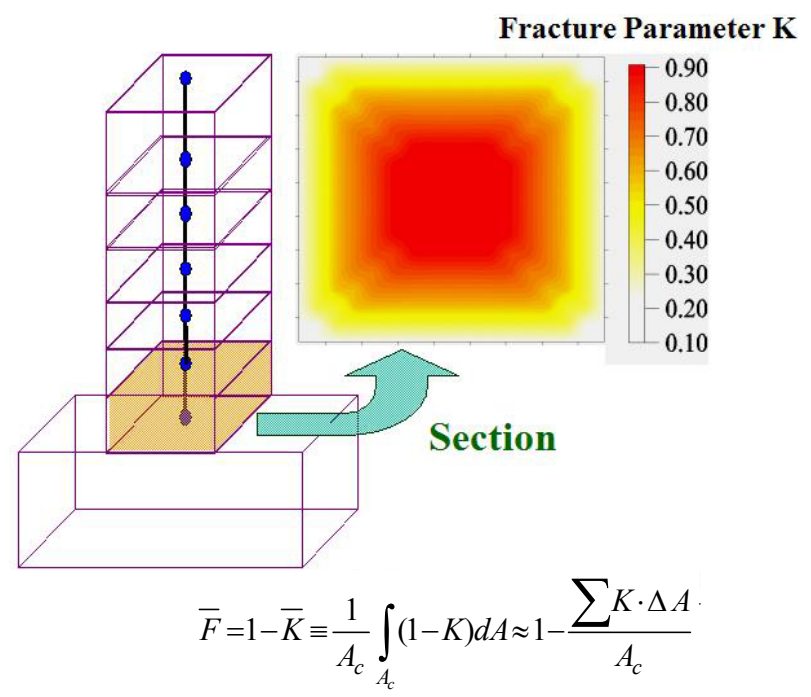

Fig. 2 Space averaging of local fracture.

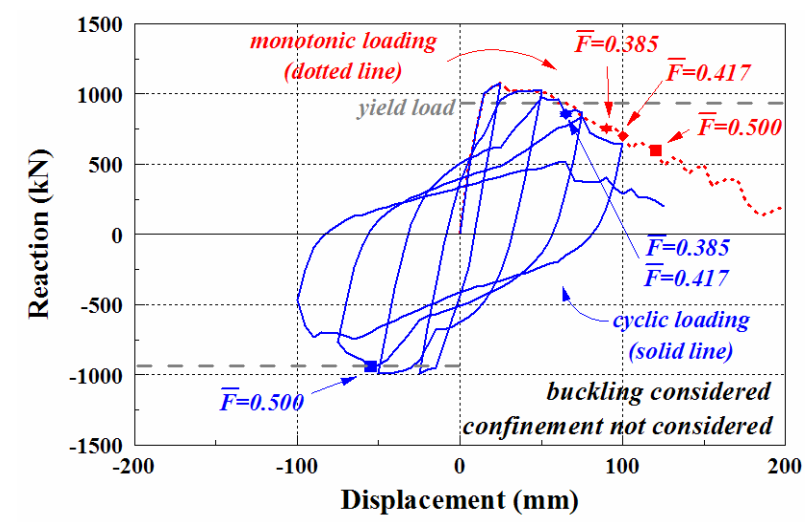

(a) $\mathrm{L}=200 \mathrm{~mm}$

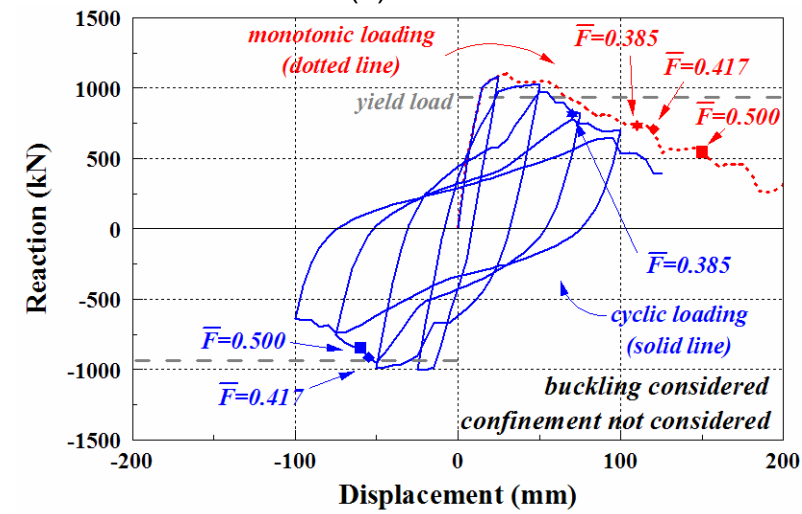

(c) $\mathrm{L}=500 \mathrm{~mm}$ librium is satisfied or the intrinsic length of localization becomes identical (El-Kashif 2004b, Jansen et al. 1997).

\section{Damage index for RC columns under one-dimensional flexure}

Figure 3.1 to Figure 3.3 show analytical results of piers that are typical for roads and railway bridges in Japan. For time integration, 240.0 seconds via static reversed cycle are specified. The dimensions of the columns illustrated in Figs. 4.1 to $\mathbf{4 . 3}$ are determined in consideration of the literature (Tanaka et al. 2001, Hoshikuma et al. 2002, Ogata 2000). The average axial compressive stress $\sigma_{N}$ is approximately $1.0 \mathrm{~N} / \mathrm{mm}^{2}$. Three types of meshes with different element lengths (denoted by L) greater than the referential size of $200 \mathrm{~mm}$ are examined as a comparative sensitivity analysis. Here, the stress-strain relation of softened concrete was adjusted according to intrinsic fracture energy in compression (El-Kashif 2004b). It was verified in advance that the analytical results are hardly affected when the element length is less than $200 \mathrm{~mm}$. The discretization over the cross section is illustrated in Figs. 4.1 to 4.3. The cross-sectional damage index $\bar{F}$ at the maximum moment section and the yield load (= the load at which the

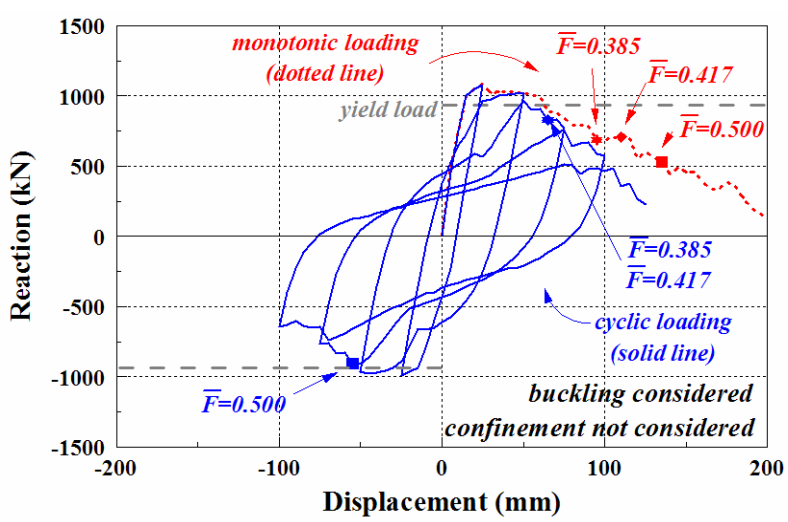

(b) $\mathrm{L}=350 \mathrm{~mm}$

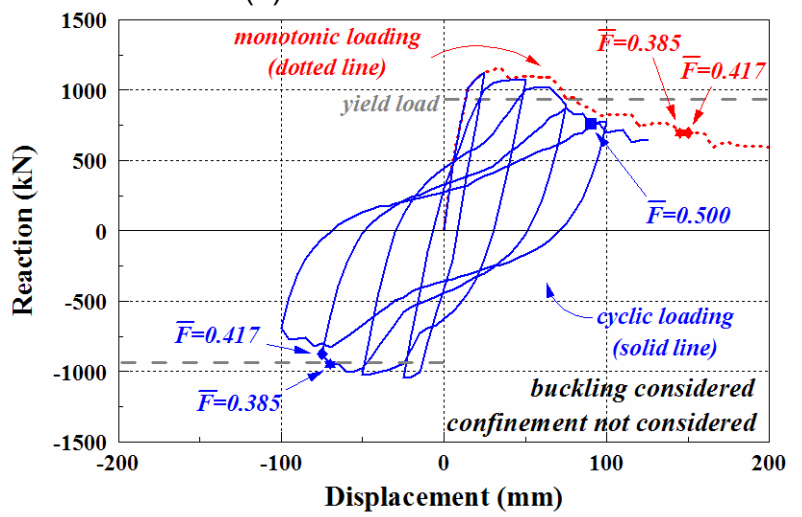

(d) $\mathrm{L}=850 \mathrm{~mm}$

Fig. 3.1 Uni-axial cyclic response of medium-scale section column $(900 \times 900 \mathrm{~mm}$ rectangular). 


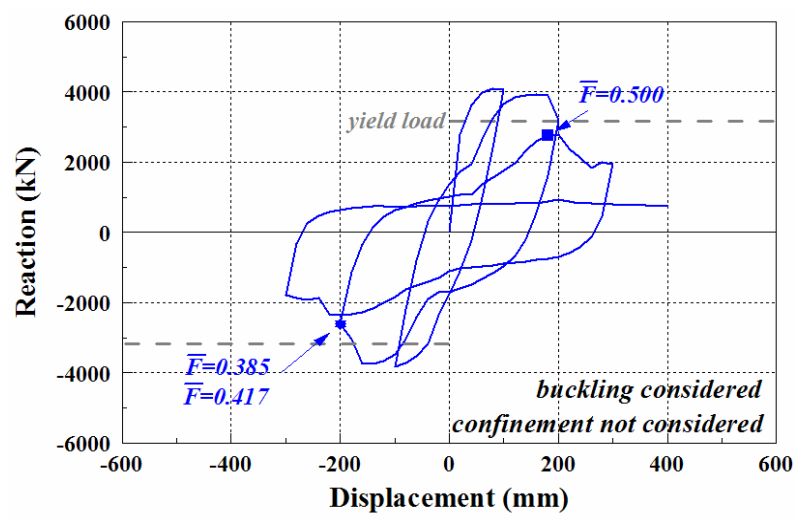

(a) $L=200 \mathrm{~mm}$

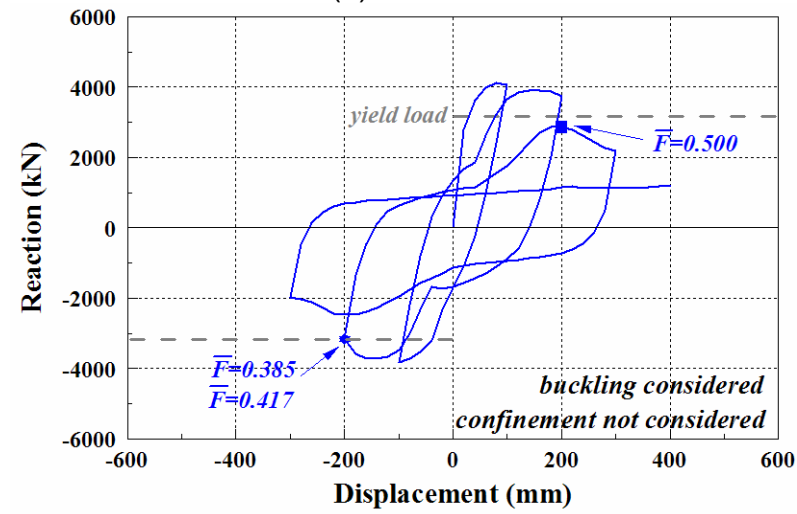

(c) $L=600 \mathrm{~mm}$

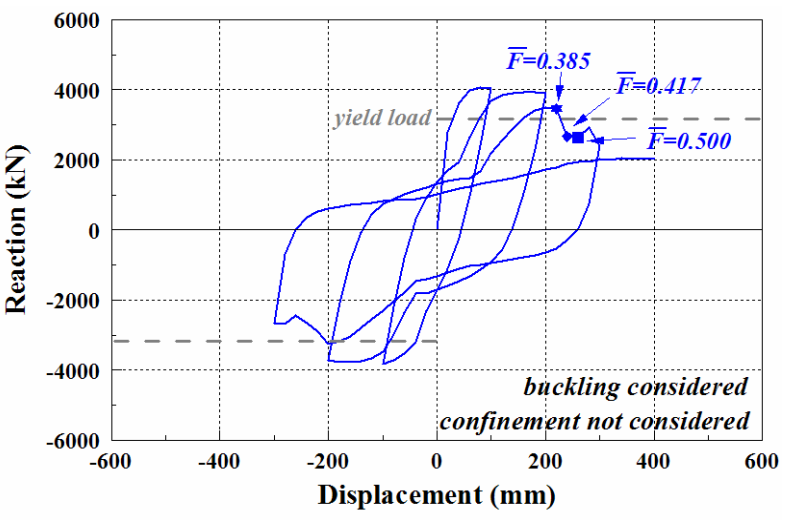

(b) $\mathrm{L}=400 \mathrm{~mm}$

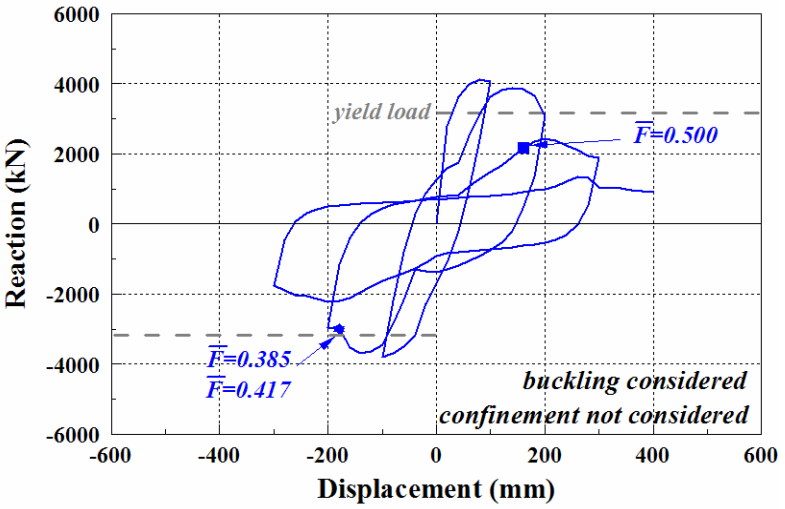

(d) $\mathrm{L}=900 \mathrm{~mm}$

Fig. 3.2 Uni-axial cyclic response of large-scale section column $(2400 \times 2400 \mathrm{~mm}$ rectangular).

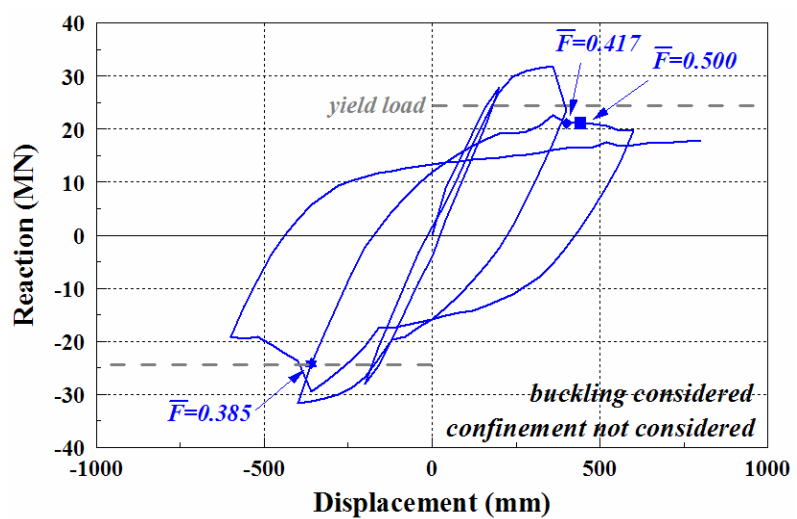

(a) $\mathrm{L}=200 \mathrm{~mm}$

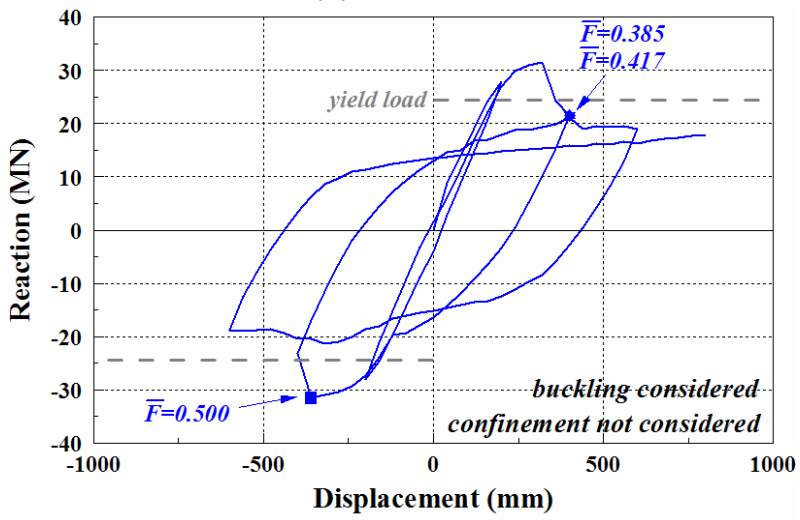

(c) $L=1000 \mathrm{~mm}$

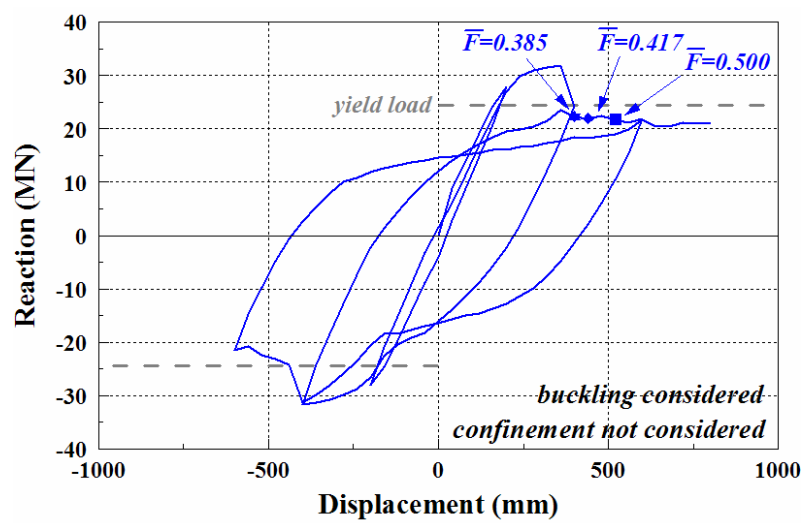

(b) $L=500 \mathrm{~mm}$

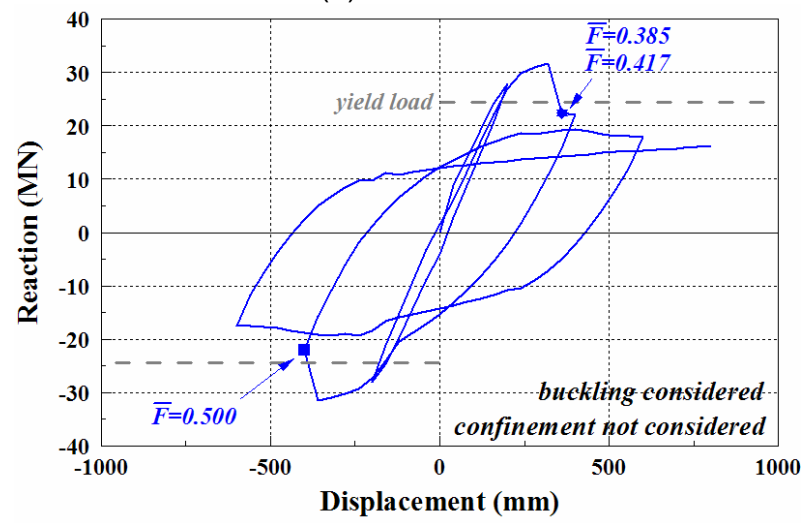

(d) $\mathrm{L}=2000 \mathrm{~mm}$

Fig. 3.3 Uni-axial cyclic response of hollow column $(4000 \times 4800 \mathrm{~mm}$ rectangular). 


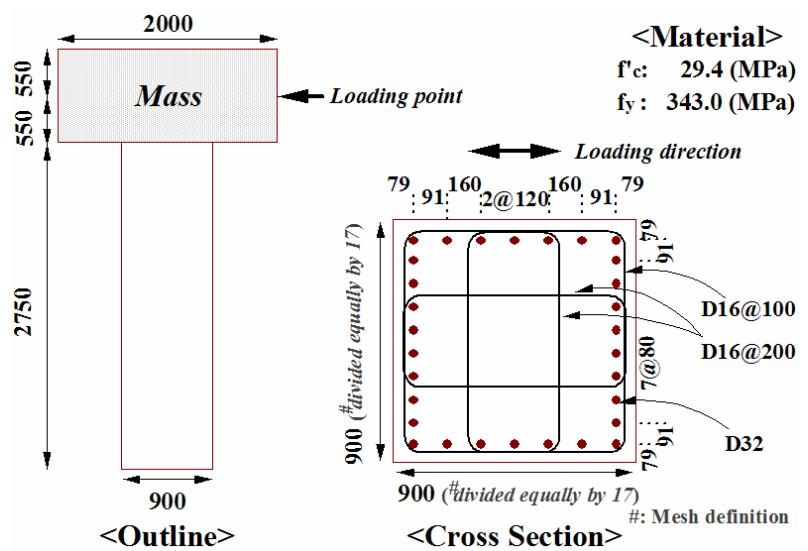

Fig. 4.1 Structural dimensions of medium-scale section column.

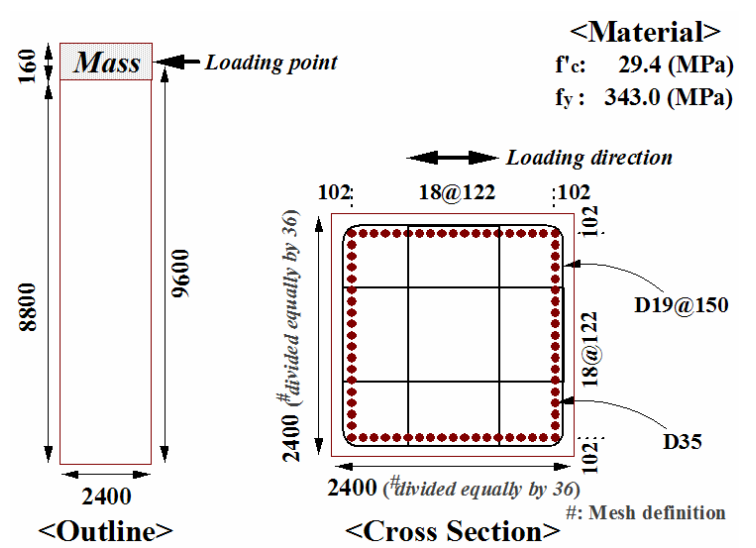

Fig. 4.2 Structural dimensions of large-scale section column.

index of the middle-scale section presented in Fig. 4.1, under four times higher axial compression. The horizontal ductility decreases. In such a situation, the displacement at which the horizontal restoring force starts to decline approximately matches the limit state of $\bar{F}$ $=0.500$. Although confinement to core concrete efficiently improves the ductility for highly axial compression, the analysis as shown in Fig. 5 does not take into account the confinement effect. The applicability of the damage index to the confinement effect is investigated in a later section.

\section{Applicability of damage index to multi-axial loading}

As the damage index can be numerically obtained under any structural dimensions and boundary conditions, it may serve as the index of 3D frame analysis scheme. Thus, its applicability to arbitrary loading paths is a major item of interest for practical versatility. For the column shown in Fig. 4.1, the horizontal skew loading is applied along 45.0 and 22.5 degrees from the X-Y coordinates. The analytical results are shown in Figs. 6.1 and 6.2. The different finite element size denoted by $L$ is checked for convergence again, because considerable strain concentration is produced at the corners of square sections.

The consistent convergence of drift responses and the damage index are obtained for both skew loadings regardless of the finite element size, and the post-peak point where the damage index reaches 0.500 corresponds to the yield load as well. The maximum strain takes place at the corners of the square cross section when skew bending is applied. Even if a very large strain is introduced and significant local damage occurs at a corner, its influence on the axial load-carrying capacity is much less since the damaged area is quite limited. In other words, it is not appropriate to judge damage of column members only using the maximum compressive strain.

Figure 8 shows the analytical results for the case

Figure 5 shows the response drift and the damage 


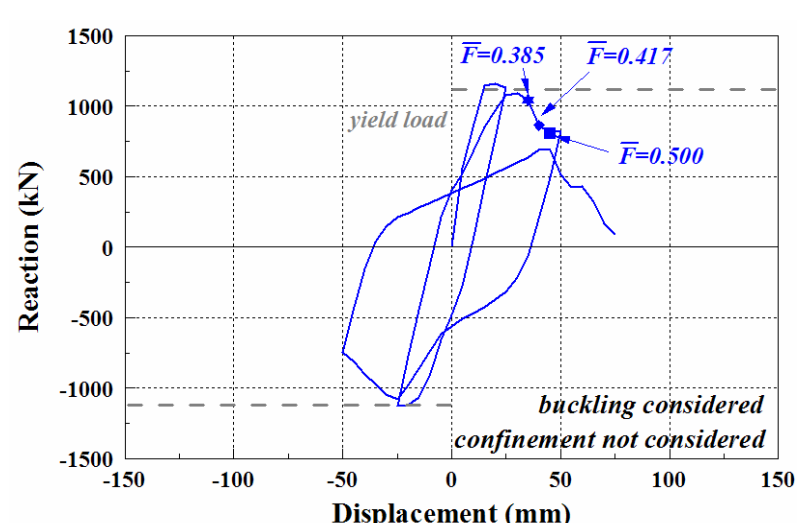

(a) $L=200 \mathrm{~mm}$

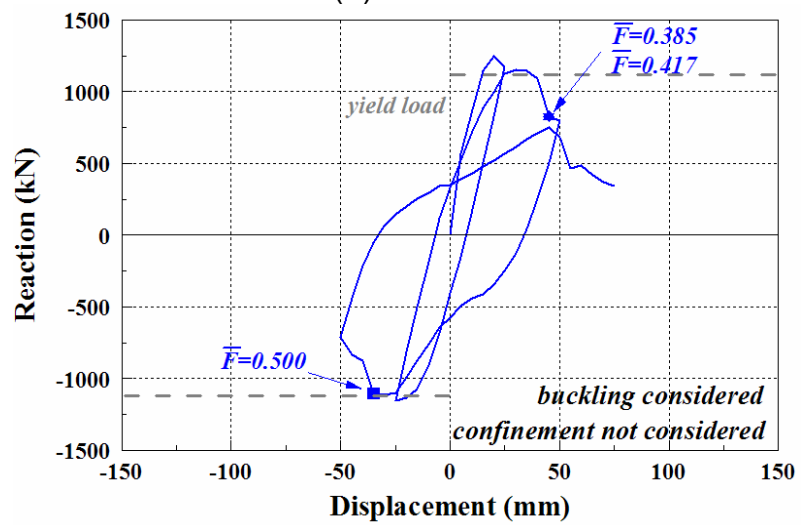

(c) $\mathrm{L}=500 \mathrm{~mm}$

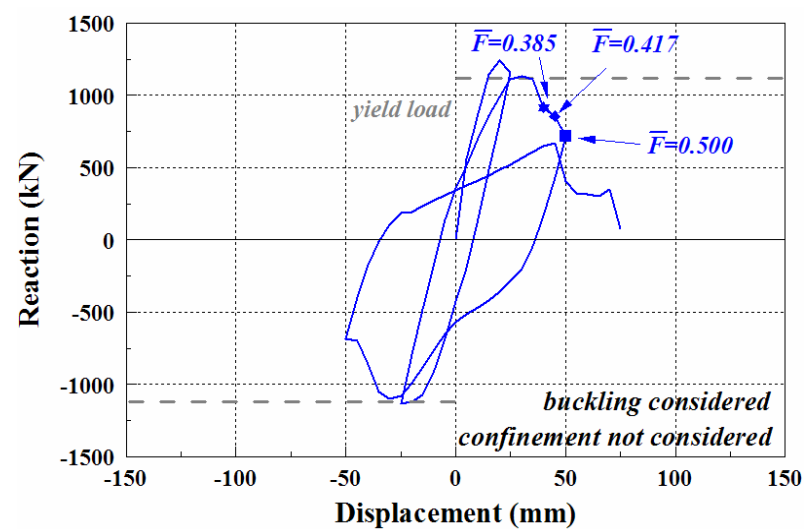

(b) $\mathrm{L}=500 \mathrm{~mm}$

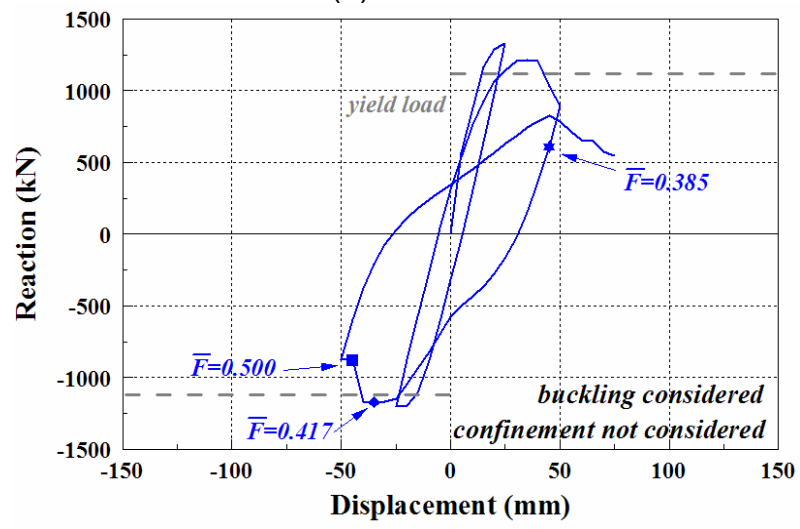

(d) $\mathrm{L}=850 \mathrm{~mm}$

Fig. 5 Effect of high axial compression on ductility ( $\sigma_{N}$ approximately $4.0 \mathrm{~N} / \mathrm{mm}^{2}$ ).

where an artificial seismic waveform was applied in 3D orthogonal directions as shown in Fig. 7 for the column shown in Fig. 4.1. Flexural compression occurs on all four sides, and greater concrete damage is also distributed along the peripheral lines. It is clear that the drift limit, which was experimentally identified just in one direction, does not fit for multi-directional seismic excitations. In fact, while the experienced maximum displacement until 0.500 of the damage index identified from reversed cyclic static loading in one direction is $75.0 \mathrm{~mm}$ as indicated in Fig. 3.1, the damage index reaches 0.500 under multi-axial dynamic loading when displacement is $-49.4 \mathrm{~mm}$ in the $\mathrm{X}$-direction and 38.0 $\mathrm{mm}$ in the Y-direction $(\mathrm{L}=200 \mathrm{~mm})$.

\section{Applicability of damage index to confined RC members}

The core concrete stress-strain relation is affected by the laterally arranged ties. Generally, concrete ductility is improved and a strength gain is achieved by increasing confinement, which leads to enhanced member ductility in flexure. This behavior can be simulated by full 3D nonlinear analysis (Pallewatta et al. 1995), and it is possible to incorporate this effect indirectly in fiber analysis through $1 \mathrm{D}$ reduced constitutive modeling. The confinement effect can be rationally characterized by a damage evolution law as shown in Fig. 9 (Pallewatta et al. 1995). Namely, the apparent strength gain and ductility improvement brought by the confinement derives from the restrained fracture evolution law, whereas the plasticity evolution is not affected by confinement. Thus, the confinement effect is treated just by modifying the fracture evolution rule accordingly.

The restoring force characteristics and corresponding damage index are indicated in Fig. 10. Hereafter, only the element length of $200 \mathrm{~mm}$ at the maximum moment region is illustrated. See Table 1 for details. For clarifying the confinement efficiency, the RC columns shown in Fig. 4.1 and 4.2 are selected as reference. The dotted lines in Fig. 10 represent analytical results without the confinement effect (same as Fig. 3, Fig. 5 and Fig. 6). The fracture evolution law of the confined core is expressed as shown in Fig. 9, based on research by Irawan and Pallewatta et al (Pallewatta et al. 1995). Transverse confinement stress is defined according to the arrangement and strength of lateral ties. In this study, $3.7 \mathrm{~N} / \mathrm{mm}^{2}$ is used for the medium-scale column as shown in Fig. 4.1 and $1.8 \mathrm{~N} / \mathrm{mm}^{2}$ is used for the large-scale column shown in Fig. 4.2, respectively.

It can be clearly seen in Fig. 10 that flexural ductility is much improved by restraining the damage evolution by providing confinement and simultaneously, the increase in the cross sectional damage index $\vec{F}$ is held 


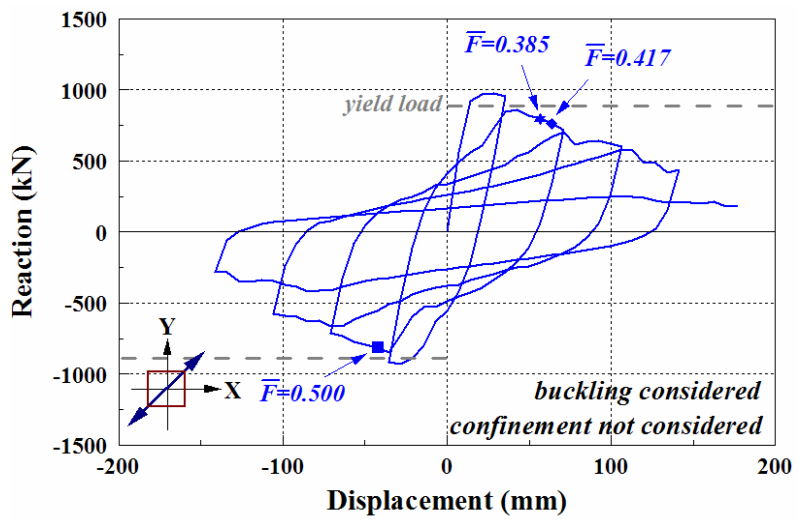

(a) $\mathrm{L}=200 \mathrm{~mm}$

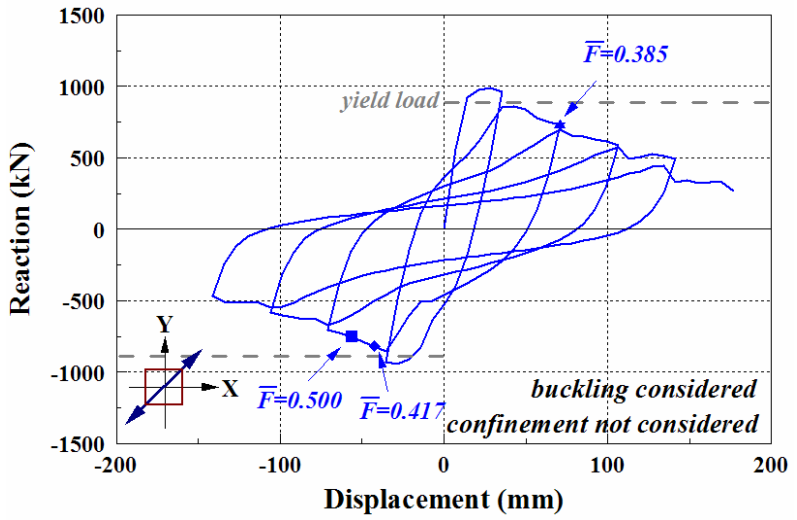

(c) $\mathrm{L}=500 \mathrm{~mm}$

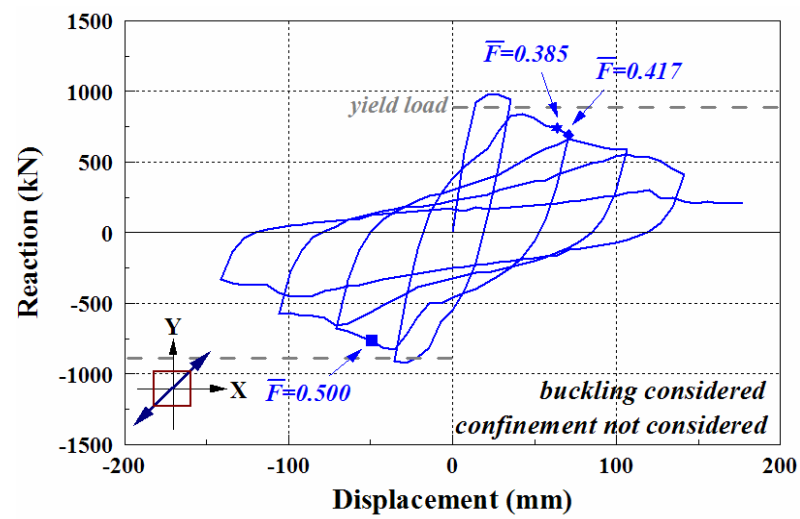

(b) $\mathrm{L}=500 \mathrm{~mm}$

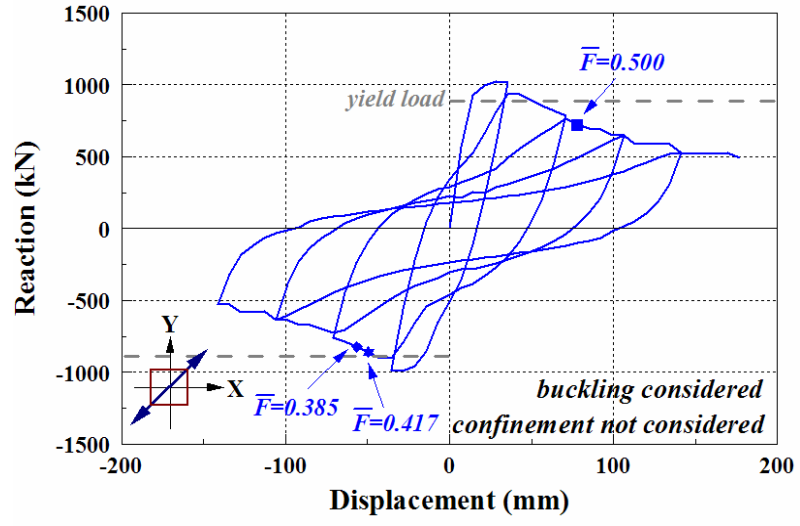

(d) $\mathrm{L}=850 \mathrm{~mm}$

Fig. 6.1 Restoring force under skew loading (45 degrees).
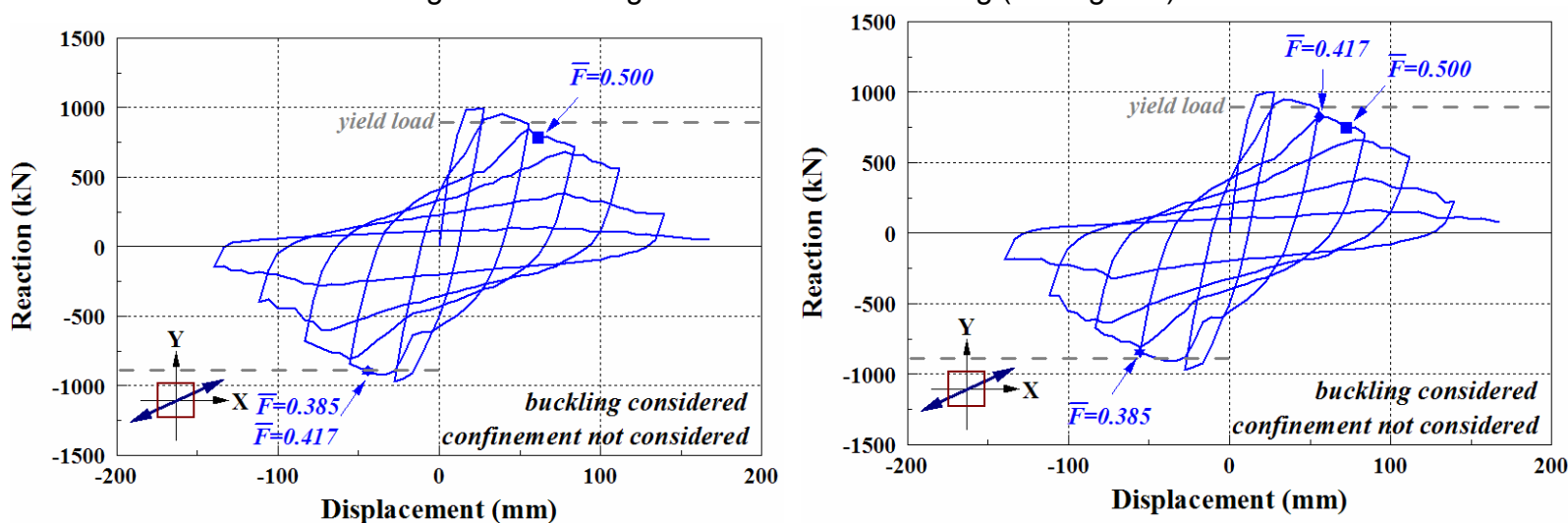

(a) $L=200 \mathrm{~mm}$

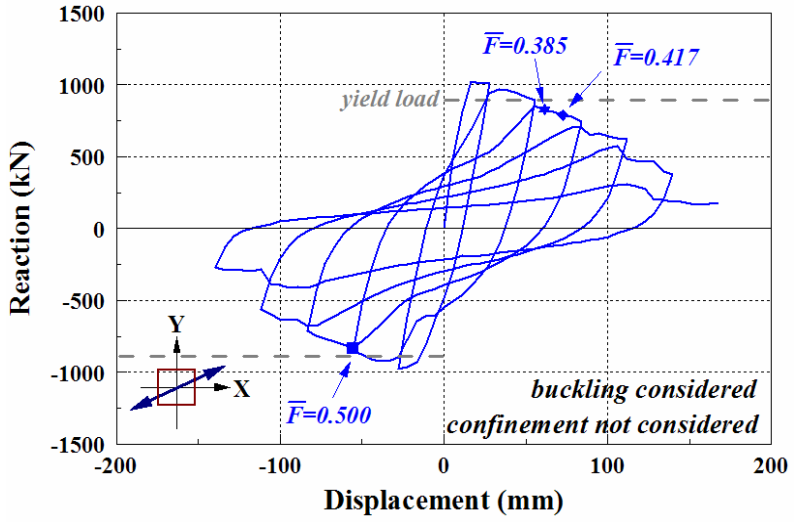

(c) $\mathrm{L}=500 \mathrm{~mm}$

(b) $\mathrm{L}=500 \mathrm{~mm}$

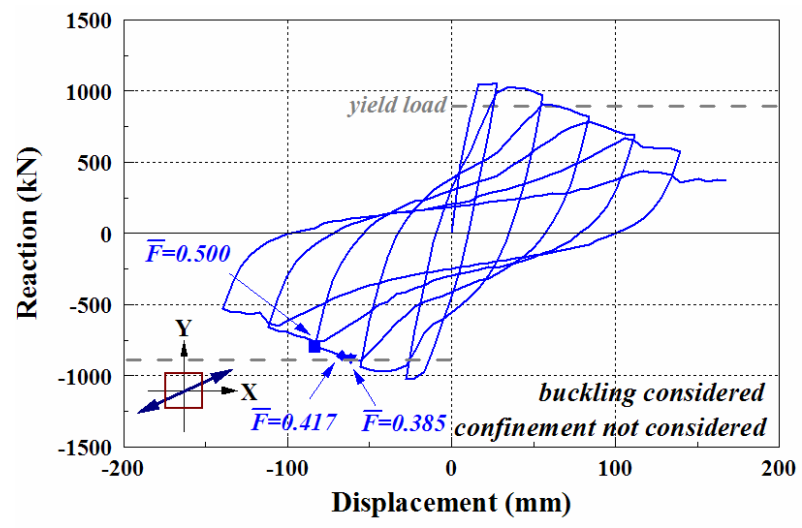

(d) $\mathrm{L}=850 \mathrm{~mm}$

Fig. 6.2 Restoring force under skew loading (22.5 degrees). 


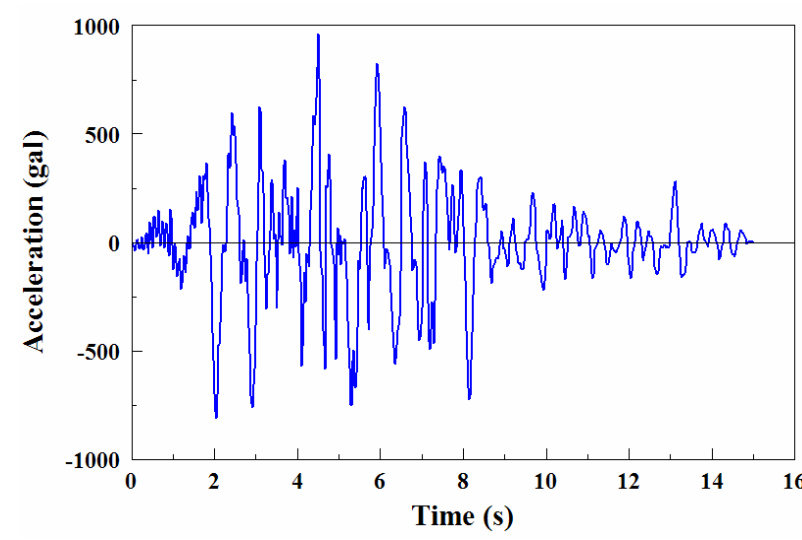

Fig. 7.1 Input seismic motion (X-direction).

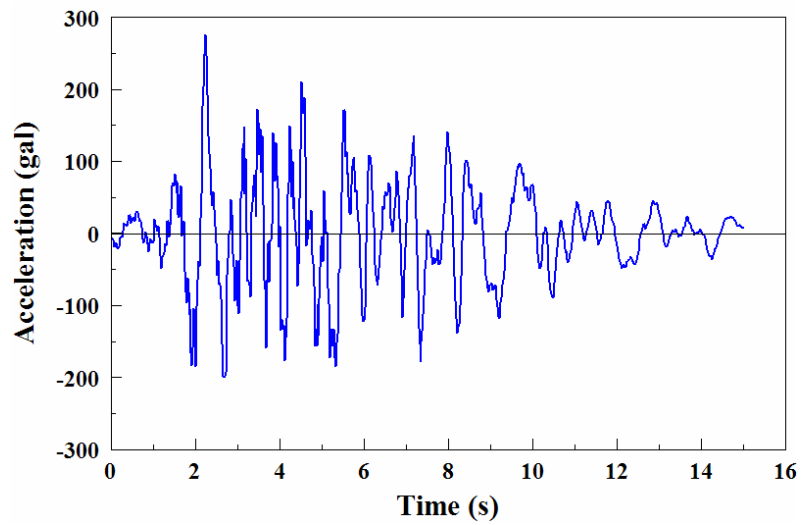

Fig. 7.3 Input seismic motion (Z-direction).

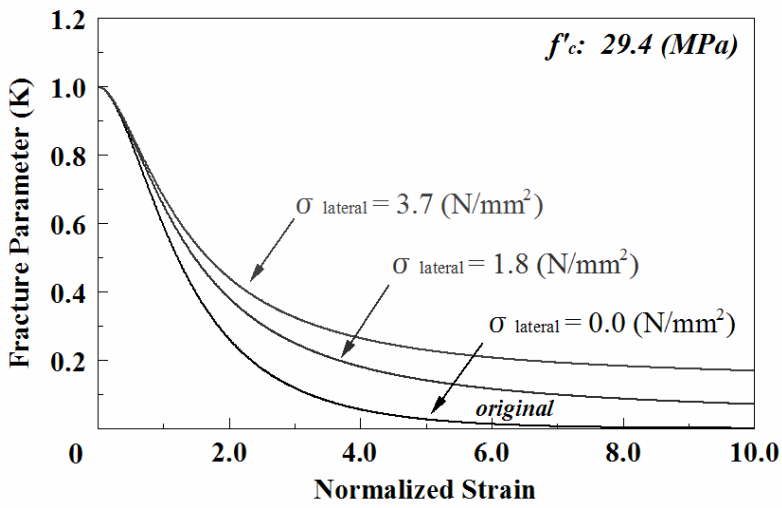

Fig. 9 Lateral confinement of concrete and delayed fracturing (Pallewatta et al. 1995).

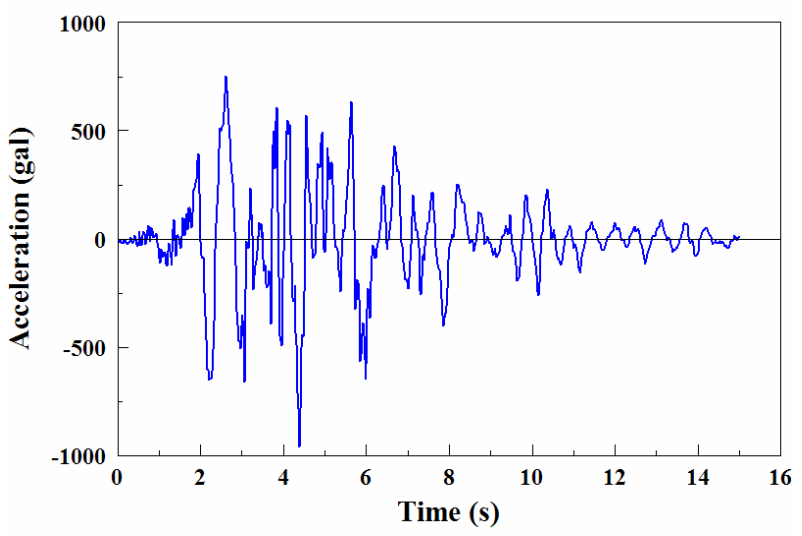

Fig. 7.2 Input seismic motion (Y-direction).

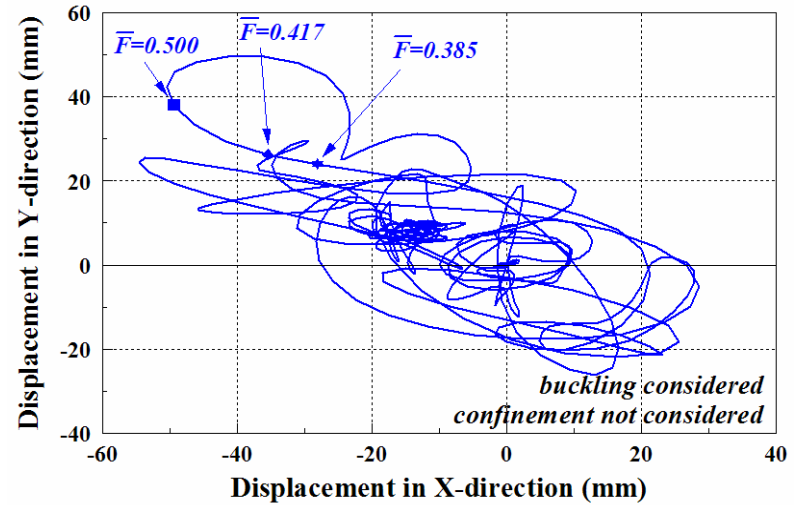

Fig. 8 Dynamic response analysis under multi-axis seismic motion $(L=200 \mathrm{~mm})$.

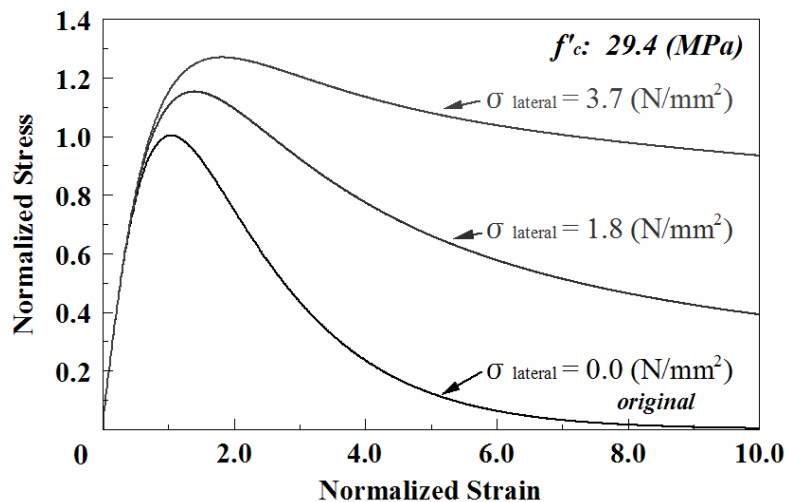

back. The response drift where the decay of restoring force is initiated coincides with the cross-sectional damage index of 0.500 as well as cases the confinement effects are not considered. Future research into compressive softening under confinement stress is needed (Lertsrisakulrat et al. 2001, Nakamura et al. 2001).

\section{Physical background of damage index}

The previous chapters verified that the response displacement where the horizontal load decreases from the peak capacity practically coincides with the cross-sectional damage index of 0.500 under various conditions. Here, let us discuss the mechanistic background of this limit state in more detail. The proposed index has the engineering advantage of stability that is insensitive to damage localization and can be applied to any 3D multi-axial flexure. Furthermore, the failure under pure axial compression occurs when approximately $\bar{F}$ reaches 0.500 , as shown in Eq. (1) to (3). Thus, the limit state $\bar{F}=0.500$ is thought to be applicable to any combination of axial compression and multi-directional bending. Physically, the damage index represents the degradation in elastic shear strain energy absorption for concrete (Maekawa et al. 2003). Plasticity is excluded from the index. In fact, the critical state 
of column safety is not plastic deformation but the loss of static axial load-carrying mechanism. Figure 11 presents the computed correlation of vertical and horizontal displacements for RC as shown in Fig. 4.1. The drift where the vertical displacement turns to decrease approximately coincides with the cross-sectional damage index of $F=0.500$ as well. Thus, it can be said that this limit state can identify the turning point of stability regarding the axial load-carrying mechanism.

It is possible to simulate residual axial compression capacity after applying reversed cyclic horizontal forces. The RC column shown in Fig. 4.1 is selected for this numerical parametric study. Figure 12 shows the rela- tion of the remaining axial capacity and the damage index just after application of the reversed cyclic flexure. The analytical results in consideration of the confinement effect are indicated in this figure. The maximum compressive load also reflects the contribution of main reinforcement. The practically unique correlation is seen for any flexural condition. Residual axial load-carrying capacity barely decreases at first, and then begins to decrease from a certain level, while the damage index increases gradually according to the initial reversed cyclic horizontal forces. Thus, the damage index is closely related to the residual axial performance after $3 \mathrm{D}$ seismic actions.

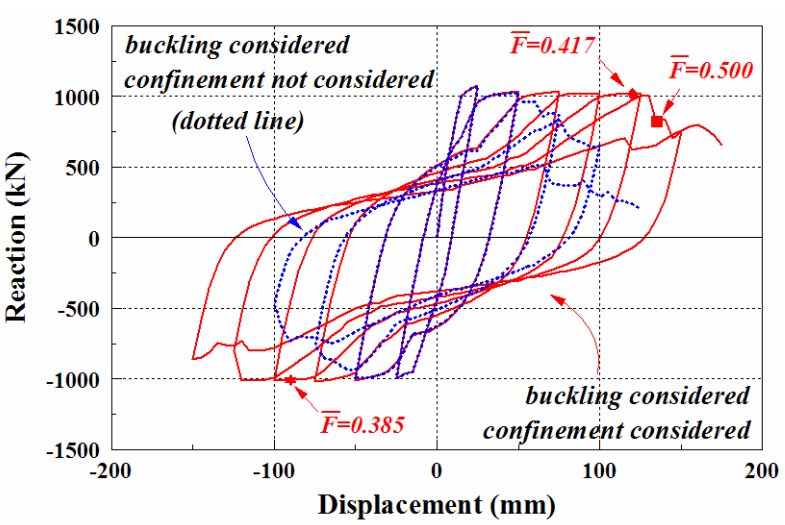

(a) Medium-scale section

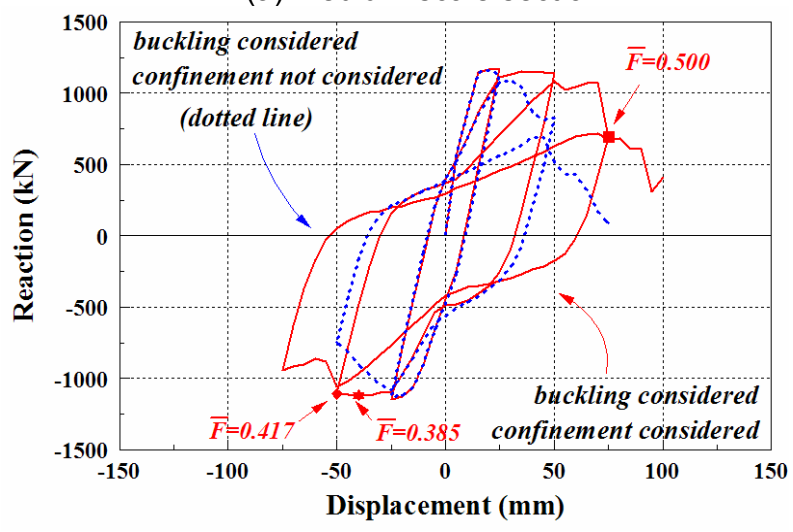

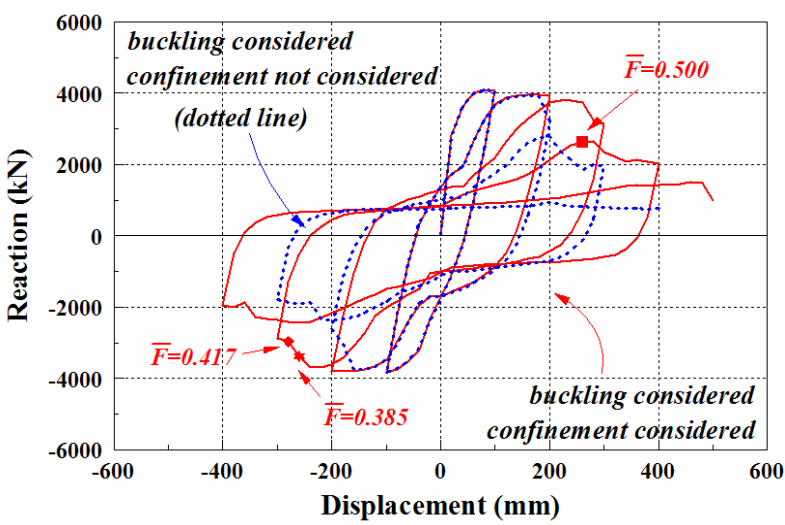

(b) Large-scale section

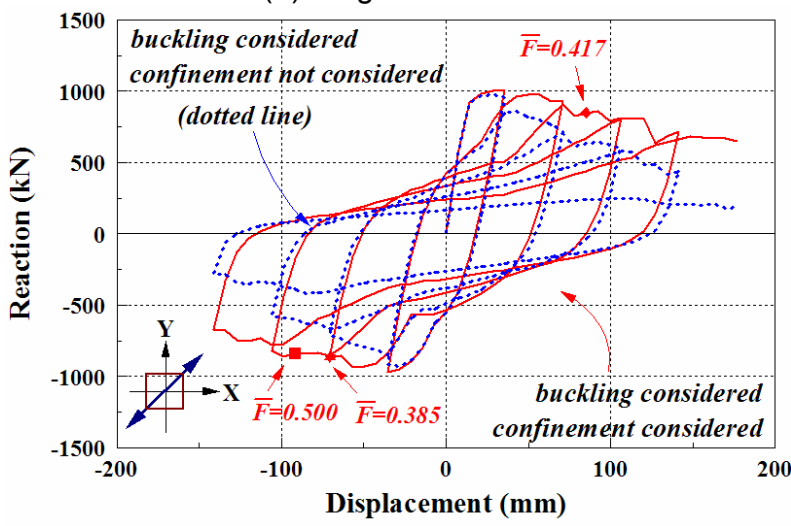

(d) Medium-scale section under skew loading (45 degrees)

(c) Medium-scale section under high compression

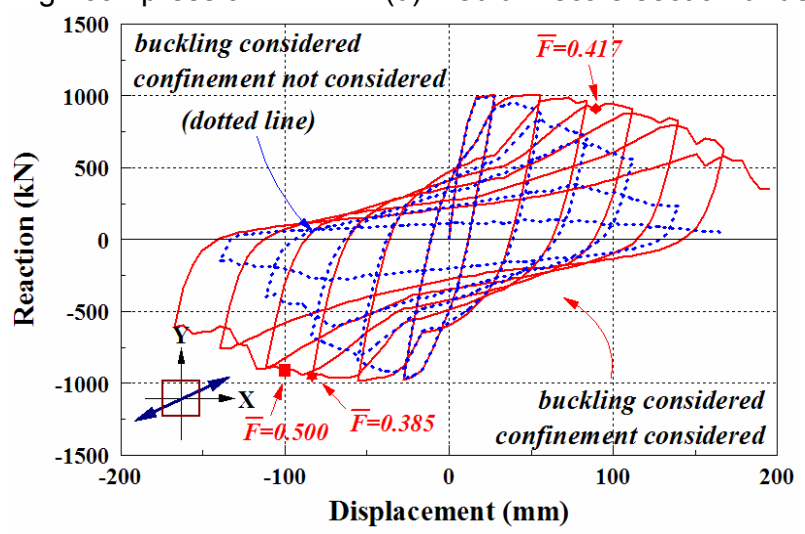

(e) Medium-scale section under skew loading (22.5 degrees)

Fig. 10 Confinement effect on response and damage index $(L=200 \mathrm{~mm})$. 
Table 1 Summary of analytical results.

\begin{tabular}{|c|c|c|c|c|c|}
\hline Case & $\begin{array}{c}\text { Base } \\
\text { element } \\
\text { length }\end{array}$ & $\begin{array}{l}\text { Confine- } \\
\text { ment effect }\end{array}$ & $\begin{array}{c}\bar{F}=0.385 \text { arrival } \\
\text { displacement \& step }\end{array}$ & $\begin{array}{c}\bar{F}=0.417 \text { arrival } \\
\text { displacement \& step }\end{array}$ & $\begin{array}{c}\bar{F}=0.500 \text { arrival } \\
\text { displacement \& step }\end{array}$ \\
\hline \multirow{8}{*}{$\begin{array}{l}\text { Medium-scale } \\
\text { section }\end{array}$} & 200 & \multirow{4}{*}{$\begin{array}{l}\text { Not } \\
\text { considered }\end{array}$} & $\begin{array}{c}+65 \mathrm{~mm} \text { (virgin loading) } \\
\text { Step }=74\end{array}$ & $\begin{array}{c}+65 \mathrm{~mm} \text { (virgin loading) } \\
\text { Step }=74\end{array}$ & $\begin{array}{c}-55 \mathrm{~mm} \text { (virgin loading) } \\
\text { Step = } 102\end{array}$ \\
\hline & 350 & & $\begin{array}{c}+65 \mathrm{~mm} \text { (virgin loading) } \\
\text { Step }=74\end{array}$ & $\begin{array}{c}+65 \mathrm{~mm} \text { (virgin loading) } \\
\text { Step }=74\end{array}$ & $\begin{array}{c}-55 \mathrm{~mm} \text { (virgin loading) } \\
\text { Step = } 102\end{array}$ \\
\hline & 500 & & $\begin{array}{c}+70 \mathrm{~mm} \text { (virgin loading) } \\
\text { Step }=75\end{array}$ & $\begin{array}{c}-55 \mathrm{~mm} \text { (virgin loading) } \\
\text { Step = } 102\end{array}$ & $\begin{array}{c}-60 \mathrm{~mm} \text { (virgin loading) } \\
\text { Step = } 103\end{array}$ \\
\hline & 850 & & $\begin{array}{l}-70 \mathrm{~mm} \text { (virgin loading) } \\
\text { Step = } 105\end{array}$ & $\begin{array}{c}-75 \mathrm{~mm} \text { (virgin loading) } \\
\text { Step }=106\end{array}$ & $\begin{array}{c}+90 \mathrm{~mm} \text { (virgin loading) } \\
\text { Step = } 139\end{array}$ \\
\hline & 200 & \multirow{4}{*}{ Considered } & $\begin{array}{l}-90 \mathrm{~mm} \text { (virgin loading) } \\
\text { Step }=179\end{array}$ & $\begin{array}{c}+120 \mathrm{~mm}(\text { virgin loading }) \\
\text { Step }=225\end{array}$ & $\begin{array}{c}+135 \mathrm{~mm} \text { (virgin loading) } \\
\text { Step }=328\end{array}$ \\
\hline & 350 & & $\begin{array}{c}+100 \mathrm{~mm}(\text { virgin loading }) \\
\text { Step }=141\end{array}$ & $\begin{array}{c}+90 \mathrm{~mm}\left(-4 \delta_{\mathrm{y}} \rightarrow+5 \delta_{\mathrm{y}}\right) \\
\text { Step }=219\end{array}$ & $\begin{array}{c}-110 \mathrm{~mm}(\text { virgin loading }) \\
\text { Step }=273\end{array}$ \\
\hline & 500 & & $\begin{array}{c}-75 \mathrm{~mm}\left(-4 \delta_{\mathrm{y}} \rightarrow+5 \delta_{\mathrm{y}}\right) \\
\text { Step }=186\end{array}$ & $\begin{array}{c}+125 \mathrm{~mm}(\text { virgin loading }) \\
\text { Step }=226\end{array}$ & $\begin{array}{c}+145 \mathrm{~mm} \text { (virgin loading) } \\
\text { Step }=330\end{array}$ \\
\hline & 850 & & $\begin{array}{c}-125 \mathrm{~mm} \text { (virgin loading) } \\
\text { Step }=276\end{array}$ & $\begin{array}{c}+140 \mathrm{~mm} \text { (virgin loading) } \\
\text { Step }=329\end{array}$ & $\begin{array}{c}-145 \mathrm{~mm} \text { (virgin loading) } \\
\text { Step }=390\end{array}$ \\
\hline \multirow{8}{*}{$\begin{array}{l}\text { Large-scale } \\
\text { section }\end{array}$} & 200 & \multirow{4}{*}{$\begin{array}{c}\text { Not } \\
\text { considered }\end{array}$} & $\begin{array}{c}-200 \mathrm{~mm} \text { (virgin loading) } \\
\text { Step = 51 }\end{array}$ & $\begin{array}{c}-200 \mathrm{~mm} \text { (virgin loading) } \\
\text { Step }=51\end{array}$ & $\begin{array}{c}+180 \mathrm{~mm}\left(-2 \delta_{\mathrm{y}} \rightarrow+3 \delta_{\mathrm{y}}\right) \\
\text { Step }=70\end{array}$ \\
\hline & 400 & & $\begin{array}{c}+220 \mathrm{~mm} \text { (virgin loading) } \\
\text { Step }=72\end{array}$ & $\begin{array}{c}+240 \mathrm{~mm} \text { (virgin loading) } \\
\text { Step }=73\end{array}$ & $\begin{array}{c}+260 \mathrm{~mm} \text { (virgin loading) } \\
\text { Step }=74\end{array}$ \\
\hline & 600 & & $\begin{array}{c}-200 \mathrm{~mm} \text { (virgin loading) } \\
\text { Step }=51\end{array}$ & $\begin{array}{c}-200 \mathrm{~mm} \text { (virgin loading) } \\
\text { Step }=51\end{array}$ & $\begin{array}{c}+200 \mathrm{~mm}\left(-2 \delta_{\mathrm{y}} \rightarrow+3 \delta_{\mathrm{y}}\right) \\
\text { Step }=71\end{array}$ \\
\hline & 900 & & $\begin{array}{c}-180 \mathrm{~mm} \text { (virgin loading) } \\
\text { Step }=50\end{array}$ & $\begin{array}{c}-180 \mathrm{~mm} \text { (virgin loading) } \\
\text { Step }=50\end{array}$ & $\begin{array}{c}+160 \mathrm{~mm}\left(-2 \delta_{\mathrm{y}} \rightarrow+3 \delta_{\mathrm{y}}\right) \\
\text { Step }=69\end{array}$ \\
\hline & 200 & \multirow{4}{*}{ Considered } & $\begin{array}{l}-260 \mathrm{~mm}(\text { virgin loading }) \\
\text { Step }=104\end{array}$ & $\begin{array}{c}-280 \mathrm{~mm} \text { (virgin loading }) \\
\text { Step }=105\end{array}$ & $\begin{array}{c}+260 \mathrm{~mm}\left(-3 \delta_{\mathrm{y}} \rightarrow+4 \delta_{\mathrm{y}}\right) \\
\text { Step }=134\end{array}$ \\
\hline & 400 & & $\begin{array}{c}+380 \mathrm{~mm} \text { (virgin loading) } \\
\text { Step }=140\end{array}$ & $\begin{array}{c}+400 \mathrm{~mm} \text { (virgin loading) } \\
\text { Step }=141\end{array}$ & $\begin{array}{c}-360 \mathrm{~mm} \text { (virgin loading) } \\
\text { Step }=179\end{array}$ \\
\hline & 600 & & $\begin{array}{l}-260 \mathrm{~mm} \text { (virgin loading) } \\
\text { Step }=104\end{array}$ & $\begin{array}{c}-280 \mathrm{~mm} \text { (virgin loading) } \\
\text { Step }=105\end{array}$ & $\begin{array}{c}+260 \mathrm{~mm}\left(-3 \delta_{\mathrm{y}} \rightarrow+4 \delta_{\mathrm{y}}\right) \\
\text { Step }=134\end{array}$ \\
\hline & 900 & & $\begin{array}{c}-220 \mathrm{~mm}(\text { virgin loading }) \\
\text { Step }=102\end{array}$ & $\begin{array}{c}-240 \mathrm{~mm} \text { (virgin loading }) \\
\text { Step }=103\end{array}$ & $\begin{array}{c}-280 \mathrm{~mm} \text { (virgin loading) } \\
\text { Step }=105\end{array}$ \\
\hline \multirow{4}{*}{ Hollow section } & 200 & \multirow{4}{*}{$\begin{array}{l}\text { Not } \\
\text { considered }\end{array}$} & $\begin{array}{c}-360 \mathrm{~mm}\left(-2 \delta_{\mathrm{y}} \rightarrow+3 \delta_{\mathrm{y}}\right) \\
\text { Step }=52\end{array}$ & $\begin{array}{c}+400 \mathrm{~mm}\left(-2 \delta_{\mathrm{y}} \rightarrow+3 \delta_{\mathrm{y}}\right) \\
\text { Step }=71\end{array}$ & $\begin{array}{c}+440 \mathrm{~mm} \text { (virgin loading) } \\
\text { Step }=72\end{array}$ \\
\hline & 500 & & $\begin{array}{c}+400 \mathrm{~mm}\left(-2 \delta_{\mathrm{y}} \rightarrow+3 \delta_{\mathrm{y}}\right) \\
\text { Step }=71\end{array}$ & $\begin{array}{c}+440 \mathrm{~mm} \text { (virgin loading) } \\
\text { Step }=72\end{array}$ & $\begin{array}{c}+520 \mathrm{~mm} \text { (virgin loading) } \\
\text { Step }=74\end{array}$ \\
\hline & 1000 & & $\begin{array}{c}+400 \mathrm{~mm} \text { (virgin loading) } \\
\text { Step }=31\end{array}$ & $\begin{array}{c}+400 \mathrm{~mm} \text { (virgin loading) } \\
\text { Step }=31\end{array}$ & $\begin{array}{c}-360 \mathrm{~mm} \text { (virgin loading) } \\
\text { Step }=50\end{array}$ \\
\hline & 2000 & & $\begin{array}{c}+360 \mathrm{~mm} \text { (virgin loading) } \\
\text { Step }=30\end{array}$ & $\begin{array}{c}+360 \mathrm{~mm} \text { (virgin loading) } \\
\text { Step }=30\end{array}$ & $\begin{array}{c}-400 \mathrm{~mm} \text { (virgin loading) } \\
\text { Step = 51 }\end{array}$ \\
\hline \multirow{8}{*}{$\begin{array}{l}\text { Medium-scale } \\
\text { section under } \\
\text { high } \\
\text { compression }\end{array}$} & 200 & \multirow{4}{*}{$\begin{array}{l}\text { Not } \\
\text { considered }\end{array}$} & $\begin{array}{c}+35 \mathrm{~mm} \text { (virgin loading) } \\
\text { Step }=28\end{array}$ & $\begin{array}{c}+40 \mathrm{~mm} \text { (virgin loading) } \\
\text { Step }=29\end{array}$ & $\begin{array}{c}+45 \mathrm{~mm} \text { (virgin loading) } \\
\text { Step }=30\end{array}$ \\
\hline & 350 & & $\begin{array}{c}+40 \mathrm{~mm} \text { (virgin loading) } \\
\text { Step }=29\end{array}$ & $\begin{array}{c}+45 \mathrm{~mm} \text { (virgin loading) } \\
\text { Step }=30\end{array}$ & $\begin{array}{c}+50 \mathrm{~mm} \text { (virgin loading) } \\
\text { Step }=31\end{array}$ \\
\hline & 500 & & $\begin{array}{c}+45 \text { mm (virgin loading) } \\
\text { Step }=30\end{array}$ & $\begin{array}{c}+45 \mathrm{~mm} \text { (virgin loading) } \\
\text { Step }=30\end{array}$ & $\begin{array}{c}-35 \mathrm{~mm} \text { (virgin loading) } \\
\text { Step }=48\end{array}$ \\
\hline & 850 & & $\begin{array}{c}+45 \mathrm{~mm}\left(+2 \delta_{\mathrm{y}} \rightarrow-2 \delta_{\mathrm{y}}\right) \\
\text { Step }=32\end{array}$ & $\begin{array}{c}-35 \mathrm{~mm} \text { (virgin loading) } \\
\text { Step }=48\end{array}$ & $\begin{array}{c}-45 \mathrm{~mm} \text { (virgin loading) } \\
\text { Step }=50\end{array}$ \\
\hline & 200 & \multirow{4}{*}{ Considered } & $\begin{array}{c}-40 \mathrm{~mm} \text { (virgin loading) } \\
\text { Step }=49\end{array}$ & $\begin{array}{c}-50 \mathrm{~mm} \text { (virgin loading) } \\
\text { Step }=51\end{array}$ & $\begin{array}{c}+75 \text { mm (virgin loading) } \\
\text { Step }=76\end{array}$ \\
\hline & 350 & & $\begin{array}{c}-45 \mathrm{~mm}\left(-2 \delta_{\mathrm{y}} \rightarrow+3 \delta_{\mathrm{y}}\right) \\
\text { Step }=52\end{array}$ & $\begin{array}{c}+65 \text { mm (virgin loading) } \\
\text { Step }=74\end{array}$ & $\begin{array}{c}+25 \mathrm{~mm}\left(-3 \delta_{\mathrm{y}} \rightarrow+4 \delta_{\mathrm{y}}\right) \\
\text { Step }=126\end{array}$ \\
\hline & 500 & & $\begin{array}{c}+60 \mathrm{~mm} \text { (virgin loading) } \\
\text { Step }=73\end{array}$ & $\begin{array}{c}-55 \mathrm{~mm} \text { (virgin loading) } \\
\text { Step = } 102\end{array}$ & $\begin{array}{c}+95 \mathrm{~mm} \text { (virgin loading) } \\
\text { Step }=140\end{array}$ \\
\hline & 850 & & $\begin{array}{c}-60 \mathrm{~mm} \text { (virgin loading) } \\
\text { Step = } 103\end{array}$ & $\begin{array}{c}+85 \mathrm{~mm} \text { (virgin loading) } \\
\text { Step = } 138\end{array}$ & $\begin{array}{c}-95 \mathrm{~mm} \text { (virgin loading) } \\
\text { Step = } 180\end{array}$ \\
\hline
\end{tabular}




\begin{tabular}{|c|c|c|c|c|c|}
\hline \multirow{8}{*}{$\begin{array}{l}\text { Medium-scale } \\
\text { section under } \\
\text { skew loading } \\
\text { (45 degrees) }\end{array}$} & 200 & \multirow{4}{*}{$\begin{array}{l}\text { Not } \\
\text { considered }\end{array}$} & $\begin{array}{c}+56.6 \mathrm{~mm} \text { (virgin loading) } \\
\text { Step }=29\end{array}$ & $\begin{array}{c}+63.6 \mathrm{~mm} \text { (virgin loading) } \\
\text { Step }=30\end{array}$ & $\begin{array}{c}-42.4 \mathrm{~mm}(\text { virgin loading }) \\
\text { Step }=47\end{array}$ \\
\hline & 350 & & $\begin{array}{c}+63.6 \mathrm{~mm} \text { (virgin loading }) \\
\text { Step }=30\end{array}$ & $\begin{array}{c}+70.7 \mathrm{~mm} \text { (virgin loading) } \\
\text { Step }=31\end{array}$ & $\begin{array}{c}-49.5 \mathrm{~mm} \text { (virgin loading) } \\
\text { Step }=48\end{array}$ \\
\hline & 500 & & $\begin{array}{c}+70.7 \mathrm{~mm} \text { (virgin loading) } \\
\text { Step }=31\end{array}$ & $\begin{array}{c}-42.4 \mathrm{~mm} \text { (virgin loading) } \\
\text { Step }=47\end{array}$ & $\begin{array}{c}-56.6 \mathrm{~mm} \text { (virgin loading) } \\
\text { Step }=49\end{array}$ \\
\hline & 850 & & $\begin{array}{c}-49.5 \mathrm{~mm} \text { (virgin loading) } \\
\text { Step }=48\end{array}$ & $\begin{array}{c}-56.6 \mathrm{~mm} \text { (virgin loading) } \\
\text { Step }=49\end{array}$ & $\begin{array}{c}+77.8 \mathrm{~mm} \text { (virgin loading) } \\
\text { Step }=72\end{array}$ \\
\hline & 200 & \multirow{4}{*}{ Considered } & $\begin{array}{c}-70.7 \mathrm{~mm} \text { (virgin loading) } \\
\text { Step }=51\end{array}$ & $\begin{array}{c}+84.9 \mathrm{~mm} \text { (virgin loading) } \\
\text { Step }=73\end{array}$ & $\begin{array}{c}-91.9 \mathrm{~mm} \text { (virgin loading) } \\
\text { Step }=104\end{array}$ \\
\hline & 350 & & $\begin{array}{c}+91.9 \mathrm{~mm} \text { (virgin loading) } \\
\text { Step }=74\end{array}$ & $\begin{array}{c}-77.8 \mathrm{~mm} \text { (virgin loading) } \\
\text { Step }=102\end{array}$ & $\begin{array}{l}+120.2 \mathrm{~mm}(\text { virgin } \\
\text { loading) Step }=138\end{array}$ \\
\hline & 500 & & $\begin{array}{c}-77.8 \mathrm{~mm}(\text { virgin loading }) \\
\text { Step }=102\end{array}$ & $\begin{array}{l}-99.0 \mathrm{~mm}(\text { virgin loading }) \\
\text { Step }=105\end{array}$ & $\begin{array}{l}+141.4 \mathrm{~mm}(\text { virgin } \\
\text { loading) Step }=141\end{array}$ \\
\hline & 850 & & $\begin{array}{l}-113.1 \mathrm{~mm}(\text { virgin } \\
\text { loading) Step }=137\end{array}$ & $\begin{array}{l}+127.3 \mathrm{~mm}(\text { virgin } \\
\text { loading) Step }=139\end{array}$ & $\begin{array}{c}-134.4 \mathrm{~mm} \text { (virgin loading }) \\
\text { Step }=180\end{array}$ \\
\hline \multirow{8}{*}{$\begin{array}{l}\text { Medium-scale } \\
\text { section under } \\
\text { skew loading } \\
\text { (22.5 degrees) }\end{array}$} & 200 & \multirow{4}{*}{$\begin{array}{l}\text { Not } \\
\text { considered }\end{array}$} & $\begin{array}{c}-44.6 \mathrm{~mm} \text { (virgin loading) } \\
\text { Step }=49\end{array}$ & $\begin{array}{c}-44.6 \mathrm{~mm} \text { (virgin loading) } \\
\text { Step }=49\end{array}$ & $\begin{array}{c}+61.3 \mathrm{~mm} \text { (virgin loading) } \\
\text { Step }=72\end{array}$ \\
\hline & 350 & & $\begin{array}{c}-55.8 \mathrm{~mm} \text { (virgin loading) } \\
\text { Step }=51\end{array}$ & $\begin{array}{c}+55.8 \mathrm{~mm}\left(-2 \delta_{\mathrm{y}} \rightarrow+3 \delta_{\mathrm{y}}\right) \\
\text { Step }=71\end{array}$ & $\begin{array}{c}+72.5 \mathrm{~mm}(\text { virgin loading }) \\
\text { Step }=74\end{array}$ \\
\hline & 500 & & $\begin{array}{c}+61.3 \mathrm{~mm} \text { (virgin loading) } \\
\text { Step }=72\end{array}$ & $\begin{array}{c}+72.5 \mathrm{~mm} \text { (virgin loading) } \\
\text { Step }=74\end{array}$ & $\begin{array}{c}-55.8 \mathrm{~mm}\left(+3 \delta_{\mathrm{y}} \rightarrow-3 \delta_{\mathrm{y}}\right) \\
\text { Step }=101\end{array}$ \\
\hline & 850 & & $\begin{array}{l}-61.3 \mathrm{~mm}(\text { virgin loading }) \\
\text { Step }=102\end{array}$ & $\begin{array}{l}-66.9 \mathrm{~mm}(\text { virgin loading }) \\
\text { Step }=103\end{array}$ & $\begin{array}{c}-83.6 \mathrm{~mm} \text { (virgin loading }) \\
\text { Step }=106\end{array}$ \\
\hline & 200 & \multirow{4}{*}{ Considered } & $\begin{array}{c}-83.6 \mathrm{~mm} \text { (virgin loading) } \\
\text { Step }=106\end{array}$ & $\begin{array}{c}+89.2 \mathrm{~mm} \text { (virgin loading) } \\
\text { Step }=137\end{array}$ & $\begin{array}{c}-100.4 \mathrm{~mm} \text { (virgin loading) } \\
\text { Step }=179\end{array}$ \\
\hline & 350 & & $\begin{array}{c}+89.2 \mathrm{~mm} \text { (virgin loading) } \\
\text { Step }=137\end{array}$ & $\begin{array}{l}+111.5 \mathrm{~mm}(\text { virgin } \\
\text { loading) Step }=141\end{array}$ & $\begin{array}{c}+122.7 \mathrm{~mm}(\text { virgin } \\
\text { loading) Step }=223\end{array}$ \\
\hline & 500 & & $\begin{array}{c}-83.6 \mathrm{~mm} \quad\left(+4 \delta_{y} \rightarrow-4 \delta_{y}\right) \\
\text { Step }=176\end{array}$ & $\begin{array}{l}-106.6 \mathrm{~mm}(\text { virgin } \\
\text { loading) Step }=180\end{array}$ & $\begin{array}{c}-106.6 \mathrm{~mm}\left(+5 \delta_{y} \rightarrow-5 \delta_{y}\right) \\
\text { Step }=270\end{array}$ \\
\hline & 850 & & $\begin{array}{l}+117.1 \mathrm{~mm}(\text { virgin } \\
\text { loading) Step }=222\end{array}$ & $\begin{array}{l}+133.8 \mathrm{~mm}(\text { virgin } \\
\text { loading) Step }=225\end{array}$ & $\begin{array}{c}+139.4 \mathrm{~mm}\left(-5 \delta_{\mathrm{y}} \rightarrow+6 \delta_{\mathrm{y}}\right) \\
\text { Step }=326\end{array}$ \\
\hline
\end{tabular}

Some attempts of performance assessment have been made by focusing on energy absorption of members (e.g. Park et al. 1985). Confinement of core concrete by lateral reinforcement makes cyclic energy absorption increase. At the same time, ductility of the column is also improved. Thus, energy absorption cannot solely indicate a specific performance. In contrast, when internal spiral steel reinforcement is provided in the RC column core, the axial load carrying capability is conserved even under large drifts causing a significant decline in energy absorption. Energy absorption can be a performance index for the simple first estimation, but it does not directly indicate the axial capacity performance of the columns that the structural member holds, although quantitative ranking is practically feasible (Tajima et al. 1998). On the other hand, the proposed damage index represents the elastically released energy from the maximum response displacement as illustrated in Fig. 13. By applying the confinement effect appropriately in constitutive models, the enhanced absorbed energy is automatically considered in the dynamic analysis and a general evaluation using the numerical scheme is thought to be possible.

\section{Conclusions}

The conclusions drawn from this work can be summarized as follows.

1) The damage level of RC beam-column members related to the stability of axial load-carrying mechanism can be simply estimated by using the proposed damage index, which is the sectional averaged fracture parameter calculated from the elasto-plastic and fracturing model for concrete. This index may offer essential information for seismic performance verification of RC beam-column structures based on member sectional damage in flexure.

2) For RC columns representative of pier dimensions used for road and railway bridges in Japan, the limit value of the cross-sectional damage index was identified as 0.500 for seismic performance level II. This is almost equivalent to the limit state for seismic performance level II as defined in member-based models.

3) The confinement effect can be consistently taken into account by installing the fracture evolution law of the confined concrete, and the limit value stated in 2) can be applied without any modification as well. 


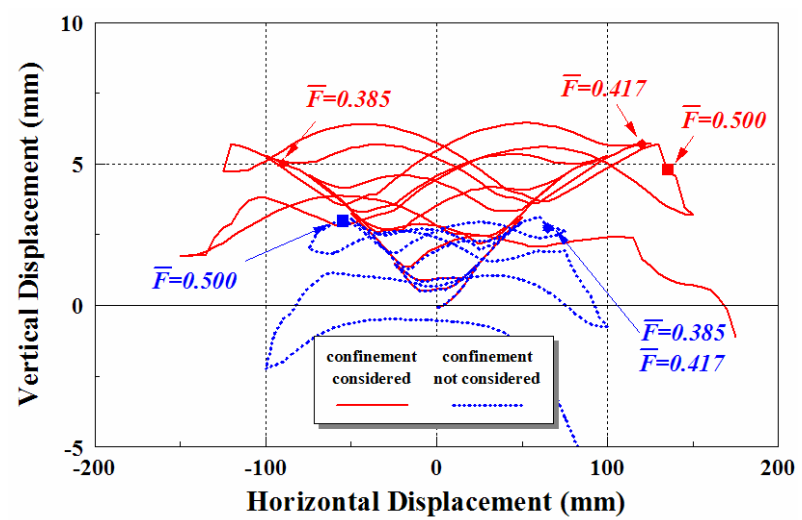

(a) Medium-scale section

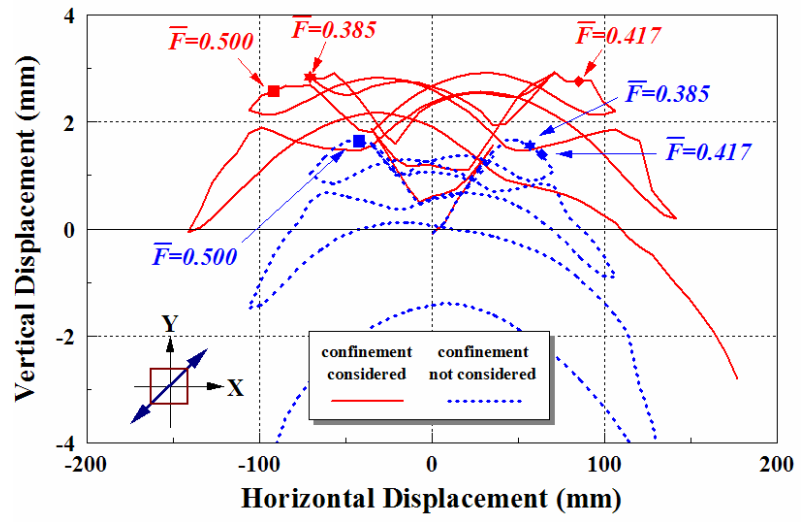

(c) Medium-scale section under skew loading

(45 degrees)

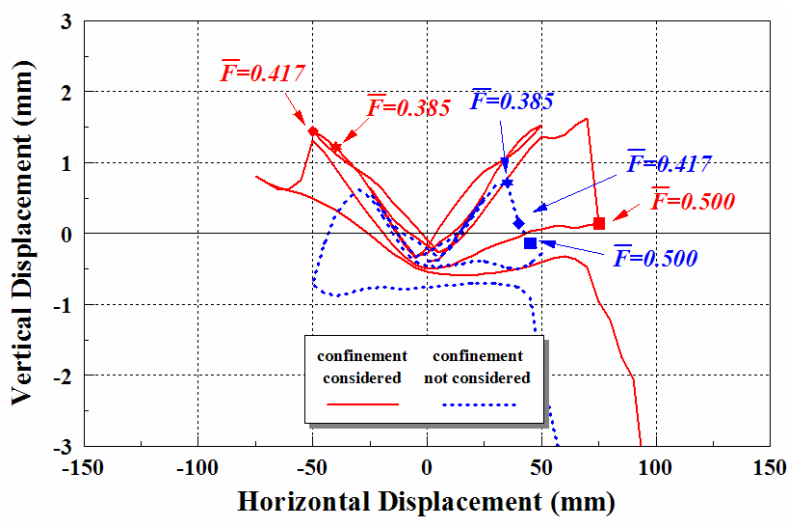

(b) Medium-scale section under high compression

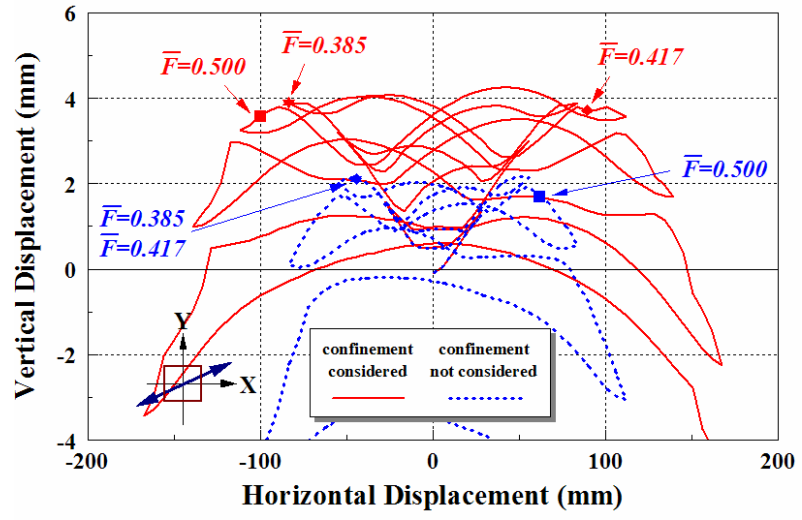

(d) Medium-scale section under skew loading (22.5 degrees)

Fig. 11 Relationship between vertical and horizontal displacement $(L=200 \mathrm{~mm})$.

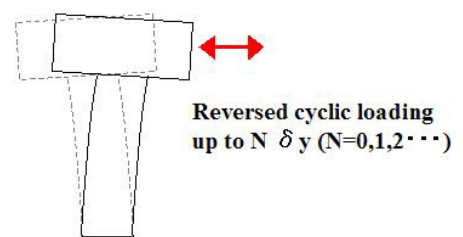

$\sqrt{5 e t u r n}$ to the original position
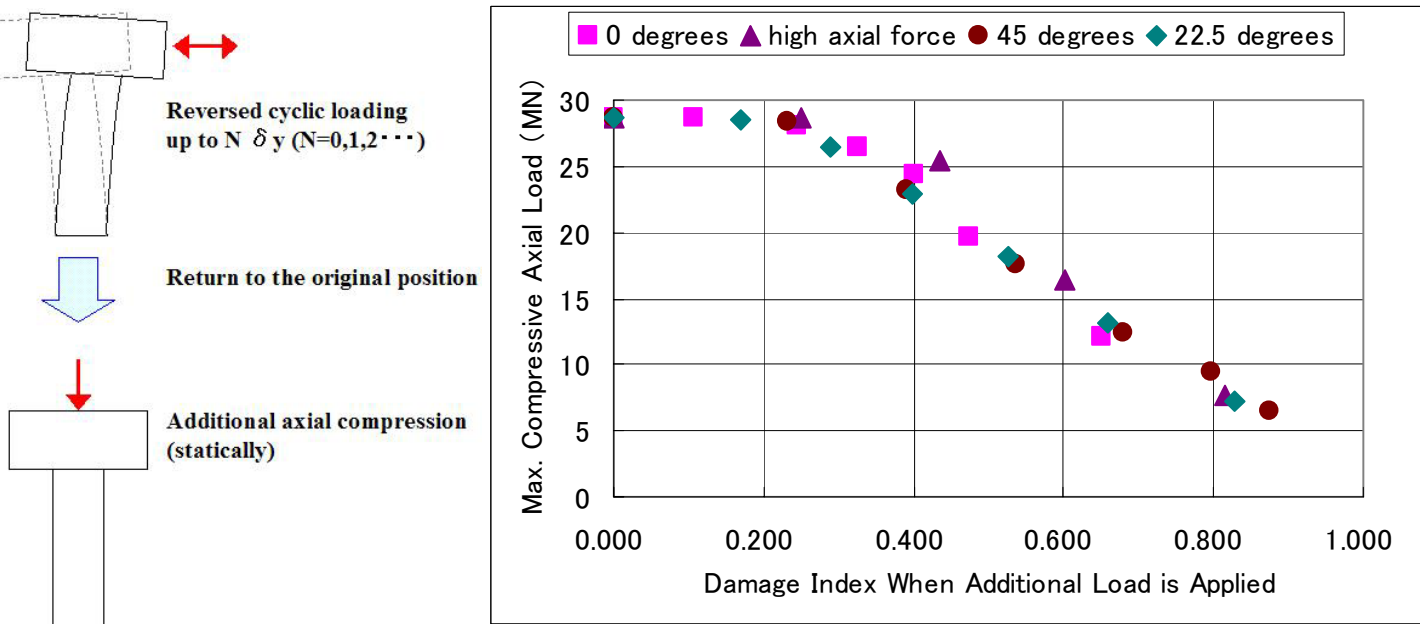

Fig.12 Investigation of residual capacity for axial loading ( $L=200 \mathrm{~mm}$, confinement considered).

4) The proposed damage index is generally applicable to multi-axis dynamic loading, varying axial forces, loading on an eccentric axis, etc.

Further study on the applicability and the limit value of cross-sectional damage is required for various structural types of arbitrary geometry and/or material strength. Especially, seismic resistant members sub- jected to higher compression are the targets of future development, because the proposed limit state index can also be applied to pure compression. The discussion in this paper is limited to normal-strength concrete. It is well known that softening behavior after the peak differs between high-strength concrete/short-fiber reinforced concrete and normal-strength concrete. The frac- 


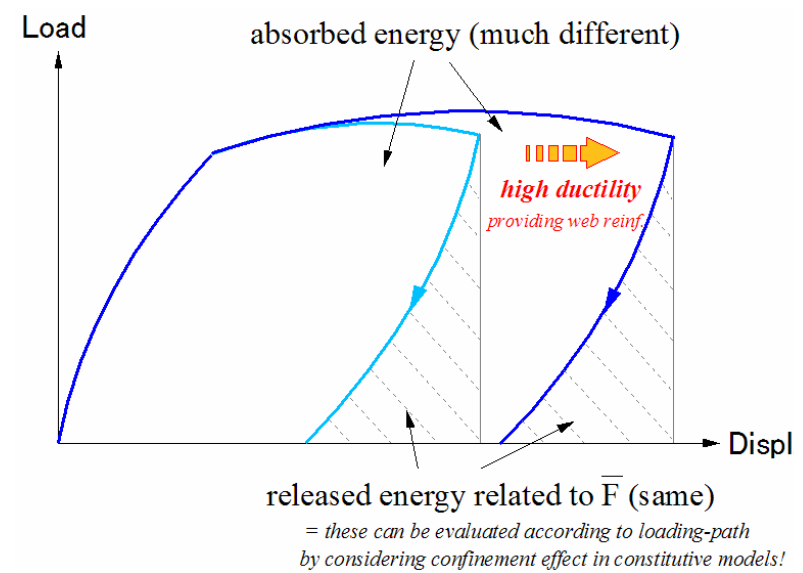

Fig. 13 Hysteresis absorbed energy and performance assessment.

ture evolution law for such types of concrete is gradually coming into qualitative focus, so we are looking forward to assessing the applicability of this damage index to other kinds of concrete to future research.

\section{References}

CEB (1996). "RC elements under cyclic loading -state of the art report." Thomas Telford.

Dhakal, R. P. and Maekawa, K. (2002a). "Modeling for postyield buckling of reinforcement." Journal of Structural Engineering, ASCE, 128 (9), 1139-1147.

Dhakal, R. P. and Maekawa, K. (2002b). "Reinforcement stability and fracture of cover concrete in reinforcement concrete members." Journal of Structural Engineering, ASCE, 128 (10), 1253-1262.

El-Kashif, K. F. and Maekawa, K. (2004a). "Time-dependent nonlinearity of compression softening in concrete." Journal of Advanced Concrete Technology, 2 (2), 233-248.

El-Kashif, K. F. and Maekawa, K. (2004b). "Time-dependent post-peak softening of RC members in flexure." Journal of Advanced Concrete Technology, 2 (3), 301-315.

Hoshikuma, J., Unjo, S. and Nagaya, K. (2002). "Flexural ductility of full-scale RC bridge columns subjected to cyclic loading." Proc. of first fib congress 2002, Osaka.

Jansen, D. and Shah. S. P. (1997). "Effect of length on compressive strain softening of concrete." Journal of Engineering Mechanics, ASCE, 123, 25-35.

JSCE (1999). "Recommendation for structural performance verification of LNG underground storage tanks." Tokyo: Japan Society of Civil Engineers, Concrete Library, (98).

JSCE (2002). "Standard Specification for Concrete Structures -2002- [Seismic Performance Verification]." Tokyo: Japan Society of Civil Engineers.

Kaizu, N., Harada, M., Koyama, N., Kanazu, T. and
Miyamoto, K. (2001). "Verification of seismic performance of in-ground LNG tank structures." Concrete Library International of JSCE, (38), 1-31.

Kato, B. (1979). "Mechanical properties of steel under load cycles idealizing seismic action." CEB Bulletin D'Information, (131), 7-27.

Lertsrisakulrat, T., Watanabe, K., Matsuo, M. and Niwa, J. (2001). "Experimental study of localization parameters in concrete subjected to compression." Concrete Library International of JSCE, (38), 225-236.

Maekawa, K., Takemura, J., Irawan, P. and Irie, M. (1993). "Triaxial elasto-plastic and continuum fracture model for concrete." Concrete Library International of JSCE, (22).

Maekawa, K., Pimanmas, A. and Okamura, H. (2003). "Nonlinear mechanics of reinforced concrete." SPON Press.

Maekawa, K. and El-Kashif K. F. (2004) "Cyclic cumulative damaging of reinforced concrete in post-peak regions." Journal of Advanced Concrete Technology, 2 (2), 257-271.

Nakamura, H. and Higai, T. (2001). "Compressive fracture energy and fracture zone length of concrete." Modeling of Inelastic Behavior of RC Structures under Seismic Loads, edited by Tanabe, T. and Benson, S., ASCE, 471-487.

Ogata, T., Suda, K. and Masukawa, J. (2000). "Transverse reinforcement and ductility of reinforced concrete high pier with hollow section." 12th World Conference on Earthquake Engineering, (1298).

Okamura, H. and Maekawa, K. (1991). "Nonlinear analysis and constitutive models of reinforced concrete." Tokyo, Gihodo-Shuppan.

Pallewatta, T. M., Irawan, P. and Maekawa, K. (1995). "Confinement effectiveness of lateral reinforcement arrangements in core concrete." Concrete Library International of JSCE, (27).

Park, Y. J., Ang, A. H. S. and Wen, Y. K. (1985). "Seismic damage analysis of reinforced concrete buildings." Journal of Structural Engineering, ASCE, $11(4), .740-757$.

Tajima, T., Shirai, N. and Moriizumi, K. (1998). "Damage evaluation of RC building on earthquake response analysis considering pullout deformation of reinforcement." Proc. of JCI, 20 (3), 31-36. (in Japanese)

Tanaka, H., Tanimura, Y., Sato, T., Takiguchi, M. and Watanabe, T. (2001). "Evaluation of damage level and ductility of reinforced concrete members." Edited by Amarjit Singh, Proc. of 1st International Structural Engineering and Construction Conference, 999-1004.

Tsuchiya, S., Ogasawara, M., Tsuno, K., Ichikawa, H., and Maekawa, K. (2001). "Multi-directional flexure behavior and nonlinear analysis of RC columns subjected to eccentric axial forces." Concrete Library International of JSCE, (37), 1-15. 
Tsuchiya, S. and Maekawa, K. (2003). "Damage index for cross section of RC beam-column members subjected to multi-axis loading." Concrete Library International of JSCE, (42), 39-54. 